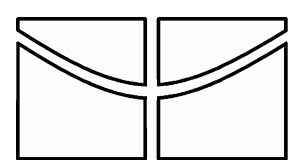

UNIVERSIDADE DE BRASÍLIA FACULDADE DE TECNOLOGIA DEPARTAMENTO DE ENGENHARIA ELÉTRICA

\title{
ESTUDO DO SISTEMA ISDB PARA RADIODIFUSÃO DIGITAL
}

\author{
Lívia Batista Maciel \\ Maria Gabriela Carneiro Moreira
}

Dissertação de Graduação em Engenharia Elétrica

Brasília, agosto de 2006 


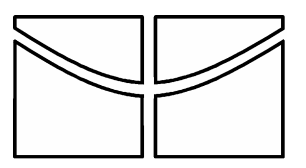

UNIVERSIDADE DE BRASÍLIA

FACULDADE DE TECNOLOGIA

DEPARTAMENTO DE ENGENHARIA ELÉTRICA

\title{
ESTUDO DO SISTEMA ISDB PARA RADIODIFUSÃO DIGITAL
}

\author{
Lívia Batista Maciel \\ Maria Gabriela Carneiro Moreira
}

Dissertação apresentada ao Departamento de Engenharia Elétrica da Universidade de Brasília, como parte dos requisitos necessários para a obtenção do grau de engenheiro eletricista.

Banca Examinadora:

LÚCIO MARTINS DA SILVA, ENE/UnB

(Orientador)

HUMBERTO ABDALLA JÚNIOR, ENE/UnB

FLÁVIO FERREIRA LIMA, ENE/UnB

Brasília, 04 de agosto de 2006. 


\section{AGRADECIMENTOS}

O que seria de mim sem as lindas pessoas que tenho em minha vida e que tantas vezes fazem tão bem a minha alma?

Agradeço a Deus por ter me capacitado para alcançar mais essa vitória. Eu a dedico aos meus pais, exemplos de coragem e sabedoria, pessoas que considero co-autoras de minhas conquistas por me apoiarem desde sempre. À toda minha família, em especial, aos meus irmãos e à tia Eva, um anjinho que encanta minha vida. $E$ aos amigos, fonte de apoio e também de muita diversão.

Agradeço também ao orientador desse projeto, o professor Lúcio Martins, que com seu conhecimento e disciplina, me transmitiu segurança para a realização desse trabalho. Um agradecimento especial a minha querida parceira, Maria Gabriela, grande amiga em quem pude confiar e compartilhar as angústias e aventuras desse projeto.

Lívia Batista Maciel

Agradeço ao meu orientador, Prof. Lúcio Martins, pela atenção e conhecimento, pois sem sua ajuda não teria sido possível concluir este trabalho. Agradeço aos meus amigos que me acompanharam no decorrer do curso e não poderia deixar de agradecer à minha parceirinha, Lívia, companheira dessa longa jornada. Um agradecimento especial às pessoas mais importantes da minha vida: minha família maravilhosa, que esteve presente em todos os momentos da minha vida sempre pronta a oferecer ajuda, dar conselhos e ouvir meus desabafos. 
RESUMO

A digitalização dos sistemas de radiodifusão de sons e imagens está acontecendo em vários países. No Brasil, o assunto tem sido discutido há alguns anos e em junho de 2006 o Governo Brasileiro expediu o Decreto №. 5820, que define o regime de transição da televisão analógica brasileira para o sistema digital e instituiu o sistema Integrated Services Digital Broadcasting (ISDB) para ser a base da digitalização da televisão brasileira. O propósito deste trabalho é estudar o sistema que foi adotado para realizar a radiodifusão terrestre de TV digital no País e compará-lo aos outros sistemas existentes no mundo. Para tal, esta dissertação tem como base o entendimento e avaliação de documentos de testes realizados, bem como as especificações técnicas de cada uma das plataformas de TV digital. 


\section{ABSTRACT}

The digitalization of the television broadcasting systems is happening all around the world. In Brazil, this subject has been discussed for a few years, and only in June of 2006 the Brazilian Government ended the debates through the Decree №. 5820 , which defines the transition regimen from the analogic television to the digital system and instituted the Integrated Services Digital Broadcasting (ISDB) to promote the digitalization of the Brazilian television. The propose of this research is to study the standard adopted to carry through the terrestrial broadcasting of digital TV in the country and to compare it to the other existing platforms. To acomplish this proposal, this thesis is based on the evaluation of field test reports, as well as the technical documents of each digital TV broadcasting system. 


\section{ÍNDICE}

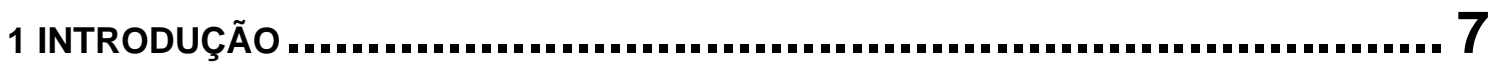

2 DA TELEVISÃO ANALÓGICA PARA DIGITAL .................................. 10

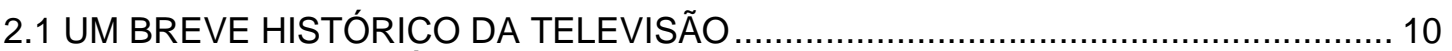

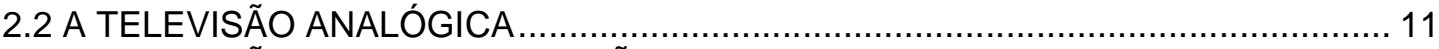

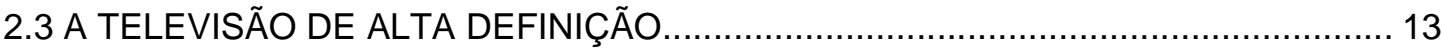

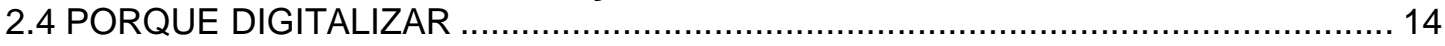

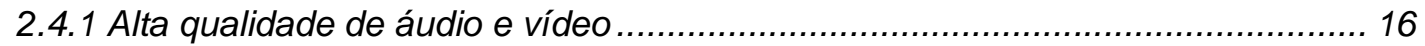

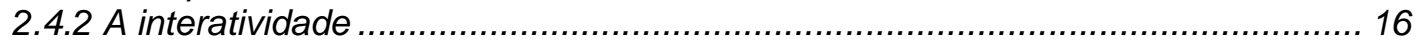

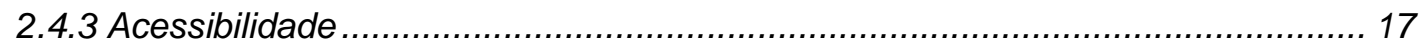

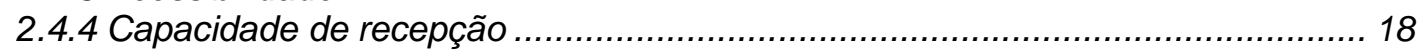

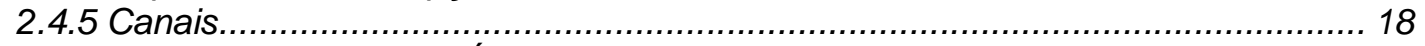

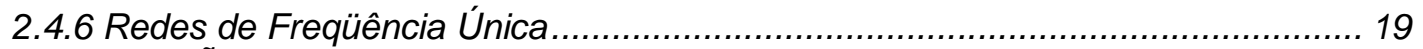

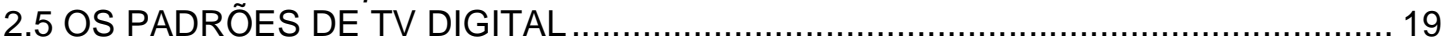

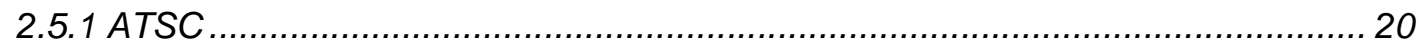

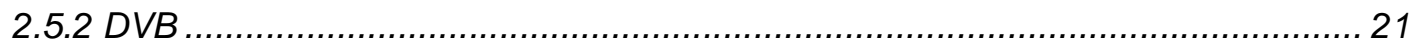

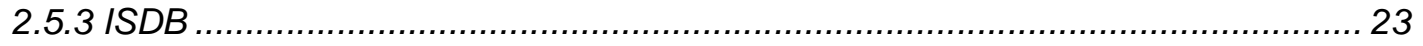

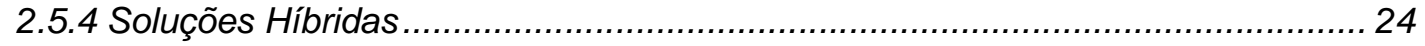

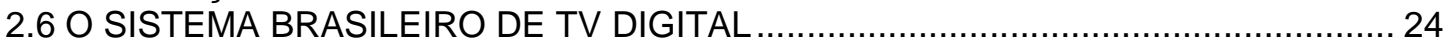

3 ELEMENTOS BÁSICOS DE UM SISTEMA DE TELEVISÃo DIGITAL .............. 26

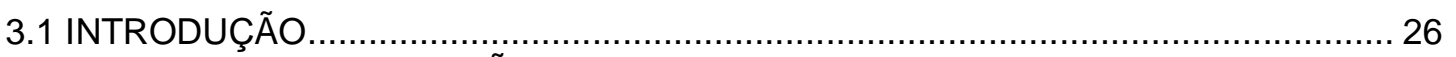

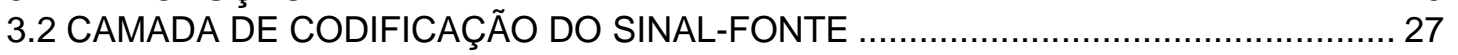

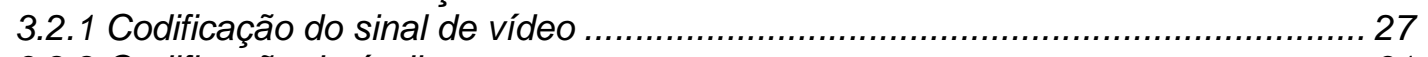

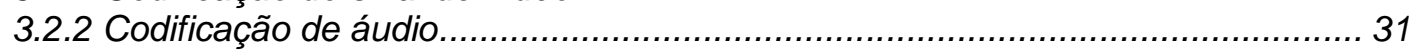

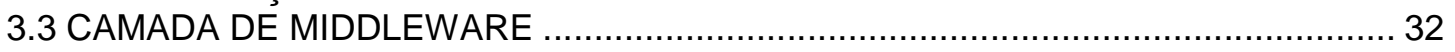

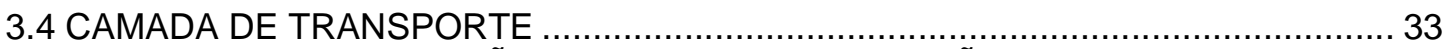

3.5 CAMADA DE CODIFICAÇÃO DO CANAL E MODULAÇÃO ................................... 34

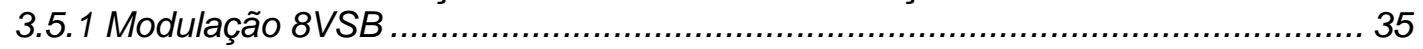

3.5.2 Modulação COFDM ........................................................................... 36

3.5.3 Técnicas de Modulação de Portadora Única Versus Sistemas de Múltiplas

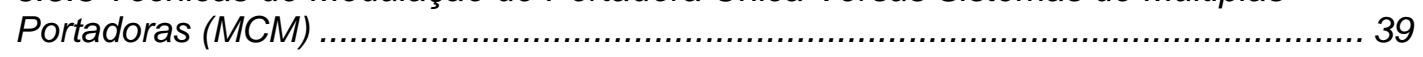

4 O SISTEMA ISDB.......................................................... 41

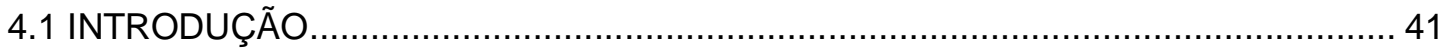

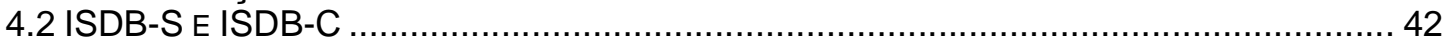

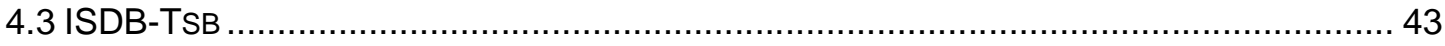

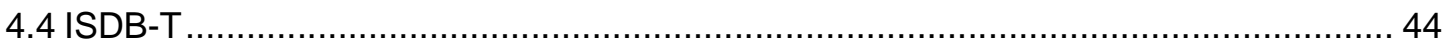

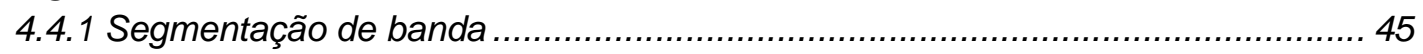

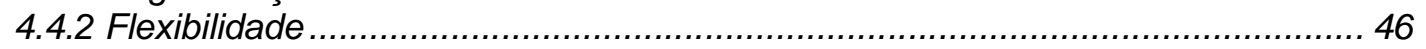

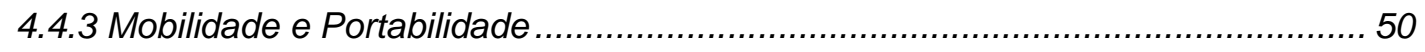




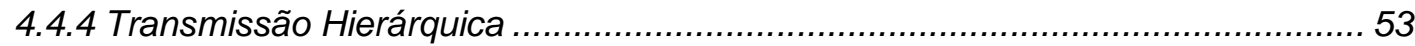

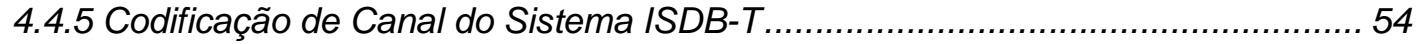

5 ANÁLISE CRÍTICA

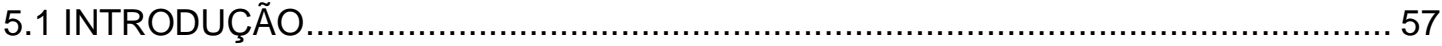

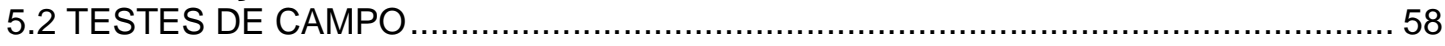

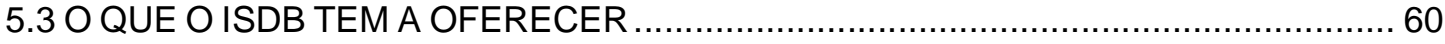

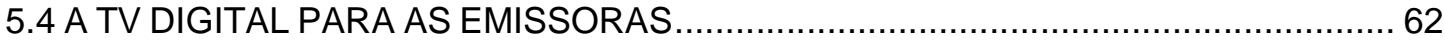

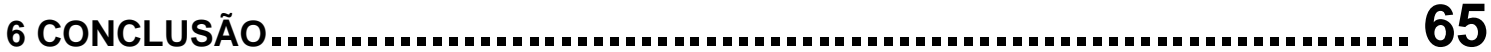

REFERÊNCIAS ................................................................. 68 


\section{ÍNDICE DAS FIGURAS}

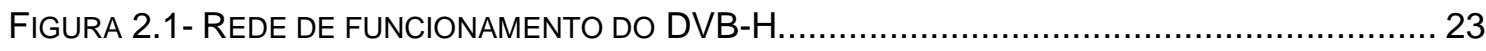

FIGURA 3.1 MODELO DE REFERÊNCIA DA ITU PARA CAMADAS DE UM SISTEMA DE TELEVISÃO

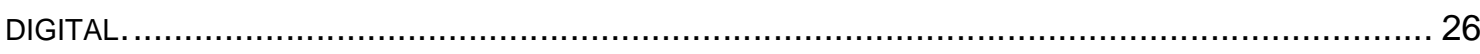

FIGURA 3.2 DIAGRAMA EM BLOCOS DA CODIFICAÇÃO DE VÍDEO MPEG2. ............................. 28

FIGURA 3.3 - ETAPA DE AMOSTRAGEM E DIGITALIZAÇÃO DO SINAL ................................... 29

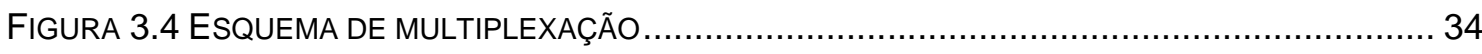

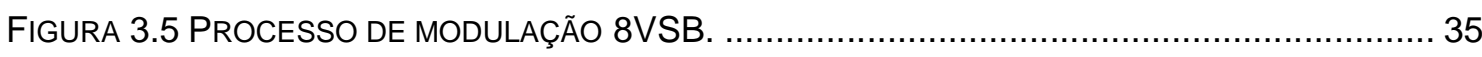

FIGURA 3.6 ORTOGONALIDADE ENTRE AS PORTADORAS NA MODULAÇÃO COFDM. ................... 37

FIGURA 3.7 PROCESSO DE CODIFICAÇÃO E MODULAÇÃO OFDM........................................ 38

FIGURA 4.1 SINAL ISDB-T DE BANDA INTEGRAL E ISDB-T DE BANDA ESTREITA. ................... 43

FIGURA 4.2 ESQUEMA DE SEGMENTAÇÃO DA BANDA .............................................. 45

FIGURA 4.3 TAXA DE BER PARA DIFERENTES TAXAS DE CODIFICAÇÃO PARA MODULAÇÃO 64QAM. 50

FIGURA 4.4 - A TRANSMISSÃO HIERÁRQUICA APLICADA NA RECEPÇÃO MÓVEL. .......................... 51

FIGURA 4.5 - ALTERAÇÃO NA INTENSIDADE DE CAMPO COM O DESLOCAMENTO ........................... 52

FIGURA 4.6 - CONVERSÃO DO ERRO BURST PARA ERRO ALEATÓRIO. .................................... 52

FIGURA 4.7 DIAGRAMA DE BLOCOS DO CODIFICADOR DE CANAL DO SISTEMA ISDB-T. ...............54

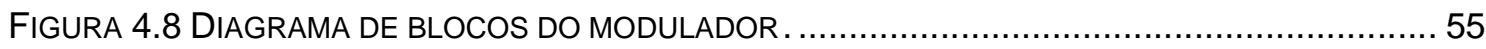

FIGURA 4.9 TAXA DE BER PARA DIFERENTES TAXAS DE CODIFICAÇÃO PARA DIFERENTES

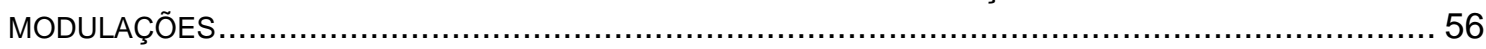

FIGURA 5.1 - TEMPO ESTIMADO PARA REALIZAR (1) AMPLIAÇÃO OU TROCA DOS EQUIPAMENTOS COM A TECNOLOGIA CORRENTE E (2) CONVERSÃO PARA O SISTEMA DIGITAL............................ 64 


\section{ÍNDICE DAS TABELAS}

TABELA 2.1 - CONFIGURAÇÕES DA QUALIDADE DE IMAGEM DA TV DIGITAL. ............................ 13

TABELA 4.1 CaRACTERÍSTICAS DOS SERVIÇOS QUE INTEGRAM O SISTEMA ISDB. .................... 42

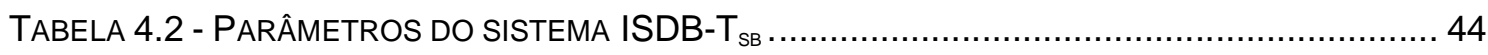

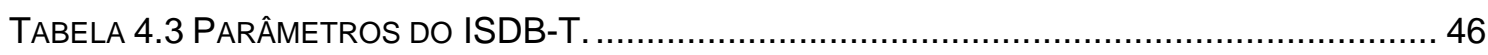

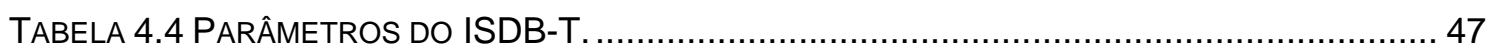




\section{LISTA DE SIGLAS}

ABERT - Associação Brasileira das Emissoras de Rádio e Televisão

ANATEL - Agência Nacional de Telecomunicações

API - Application Programming Interface

ARIB - Association of Radio Industries and Businesses

ATSC - Advanced Television Systems Committee

BER - Bit Error Rate

BPSK - Binary Phase-Shift Keying

COFDM - Coded Orthogonal Frequency Division Multiplexing

DASE - DTV Application Software

DCT - Transformada Discreta de Co-seno

Dibeg - Digital Broadcasting Experts Group

DVB - Digital Video Broadcasting

EDTV - Enhanced Definition Television

FCC - Federal Communications Commission

FEC - Forward Error Correction Code

FI - Freqüência Intermediária

HDTV - High Definition Television

ISDB - Integrated System Digital Broadcasting

ITU - União Internacional de Telecomunicações

LDTV - Low Definition Television

MCM - Multiple Carrier Modulation

MHP - Multimedia Home Plataform

MPEG - Moving Picture Expert Group 2

NTSC - National Television System Committee

PAL - Phase Alternation Line

PES - Packetized Elementary Streams

16QAM - Quadrature Amplitude Modulation

QPSK - Quadrature Phase Shift Keying

RLC - Run Lenght Code

SBTVD - Sistema Brasileiro de Televisão Digital

SCM - Single Carrier Modulation

SECAM - Sequencial Couleur Avec Mémoire

SET - da Sociedade Brasileira de Engenharia de Televisão e Telecomunicações 
SDTV - Standard Definition Television

SORCER - Sistema OFDM com Redução de Complexidade por Equalização

Robusta

TC8PSK - Trellis-Coded 8 Phase-Shift Keying

TS - Transport Streams

UHF - Ultra High Frequency

VLC - Variable Lenght Code

VSB - Vestigial Side Band

VHF - Very High Frequency 


\section{INTRODUÇÃO}

Nos últimos anos, o Governo Brasileiro e um grande número de pesquisadores e instituições debateram a necessidade e os caminhos para a implantação da TV digital no Brasil. Nessa discussão estava a possibilidade da adoção de padrões já existentes em outros países ou de desenvolver um padrão brasileiro.

A televisão digital é um sistema de radiodifusão televisiva que transmite sinais digitais em lugar dos analógicos. Mais eficiente no que diz respeito à recepção dos sinais, a transmissão digital está trazendo com ela uma série de inovações, tais como a possibilidade de se ter uma imagem com um maior grau de resolução, som estereofônico envolvente, disponibilidade de vários programas num mesmo canal e a possibilidade de haver interatividade entre o receptor e o emissor. Sua idéia mais atrativa é a capacidade de possibilitar a convergência entre diversos meios de comunicação eletrônicos, entre eles a telefonia, a radiodifusão, a transmissão de dados e o acesso à Internet. Essa nova visão da televisão implica na possibilidade de uma maior gama de serviços ofertados e o surgimento de inúmeras facilidades tendo como ponto de partida a criatividade na exploração das vantagens que a TV digital propicia.

Anteriormente à TV Digital, outras importantes tecnologias foram desenvolvidas, como a TV a cabo ou via satélite, porém esses meios não alcançaram a abrangência da televisão aberta (terrestre), que no Brasil está presente em mais de $90 \%$ dos domicílios. Essa grande disseminação da televisão e a importância que ela possui como meio de informação e entretenimento para a população fizeram com que o governo brasileiro decidisse utilizar a TV Digital para promover a inclusão digital e, com ela, a inclusão social.

Nesse contexto, o objetivo desse trabalho foi desenvolver um estudo sobre os conceitos de TV digital, suas principais características, suas vantagens e 
desvantagens, sua evolução histórica, seu desenvolvimento em outros países, uma comparação entre os padrões que foram desenvolvidos nos Estados Unidos, na Europa e no Japão, e por ser um assunto que está em discussão no Brasil, quais as implicações que existem quanto à sua implantação no país.

No início dos nossos estudos, o Brasil ainda passava pela fase de decisão sobre qual seria o melhor padrão de TV digital a ser adotado no país. Nesse cenário, o foco principal do nosso trabalho era fazer um estudo do padrão de TV digital adotado no Japão, o Integrated System Digital Broadcasting - ISDB , bem como das vantagens e desvantagens que o Brasil teria se adotasse esse sistema, até então visto como o mais cotado a ser escolhido. Já na fase final do trabalho, o governo brasileiro apresentou à população sua decisão, fazendo realmente a escolha pelo padrão japonês.

O corpo desse trabalho está dividido em quatro capítulos, no primeiro abordaremos os conceitos sobre televisão, fazendo uma comparação entre a televisão analógica e a digital, evidenciando as vantagens que essa tecnologia apresenta em relação àquela. Nesse capítulo também serão introduzidos os principais conceitos em relação à televisão digital, além da apresentação dos padrões que foram desenvolvidos nos Estados Unidos, na Europa e no Japão.

O segundo capítulo é composto pelas informações a cerca das camadas que constituem os padrões de TV digital. Cada padrão é caracterizado pelas diferenças que apresentam nas camadas de codificação do sinal fonte, multiplexação, modulação e de middleware, ferramenta que possibilita a interatividade entre o receptor e o emissor. Nesse capítulo são evidenciadas as definições de cada camada, as tecnologias adotadas, as diferenças existentes em cada padrão e a implicação disso em seu desempenho.

No terceiro capítulo são apresentadas de forma mais detalhada as informações técnicas do ISDB. Criado no Japão pelo consórcio Digital Broadcasting Experts Group (DiBEG), esse padrão não foi desenvolvido apenas objetivando a transmissão de sinais digitais de televisão, mas como uma plataforma tecnológica com múltiplos serviços. O ISDB possui uma estrutura de funcionamento muito bem desenvolvida, apresentando excelente desempenho no que se refere à imunidade a interferência. Além disso, por ter sido desenvolvido para oferecer múltiplos serviços, apresenta um suporte tecnológico que permite a convergência das transmissões televisivas com a internet, telefones celulares da terceira geração, entre outros. Uma das suas principais inovações tecnológicas é a questão da mobilidade e portabilidade associada a seus serviços de transmissão. 
No último capítulo desse trabalho será apresentada uma análise crítica sobre o que a implantação da TV digital representa para o Brasil, levando em consideração a viabilidade dessa transformação, as questões sócio-econômicas que a delimitam e os planos que o governo brasileiro estabeleceu no decreto que foi assinado, confirmando a escolha do padrão a ser adotado,

Antes mesmo de o padrão ISDB ter sido escolhido pelo governo brasileiro, o foco da análise presente em nosso trabalho era a determinação das vantagens de se adotar esse padrão no país. Nesse último capítulo, será feito um levantamento das vantagens técnicas que o padrão ISDB possui que o diferencia dos demais, caracterizando seu excelente desempenho, as principais questões que levaram o governo a fazer essa escolha e algumas estimativas quanto ao tempo e as condições financeiras para que ocorra a migração das emissoras para o sistema digital. 


\section{DA TELEVISÃO ANALÓGICA PARA A DIGITAL}

A televisão exerce um importante papel na sociedade. É por meio dela que grande parte da população tem acesso às informações, funcionando, dessa forma, como um importante instrumento de formação de opinião. É também um meio de entretenimento muito barato e, por conta disso, um dos mais utilizado no país. Presente em cerca de $90 \%$ das residências [1], atinge desde as áreas urbanas até as regiões mais remotas do País, alcançando todas as classes sociais.

$O$ advento da televisão representou um marco no desenvolvimento dos meios de comunicação e, desde então, grandes investimentos têm sido realizados na busca do aprimoramento do seu desempenho. Um dos principais marcos na evolução da televisão foi, certamente, a realização da transmissão da imagem em cores, em substituição ao sistema de transmissão em preto-e-branco. Agora, a digitalização da televisão representa um marco evolutivo mais importante com maior impacto que a TV a cores.

\subsection{UM BREVE HISTÓRICO DA TELEVISÃO}

O funcionamento das primeiras estações de televisão em preto e branco iniciou-se em 1941, nos Estados Unidos da América. No Brasil, a primeira emissora começou a funcionar somente em 1952, em São Paulo.

As primeiras transmissões regulares de televisão colorida foram realizadas também pelos Estados Unidos, em 1953. O sistema de televisão analógico 
desenvolvido pelos americanos, o NTSC - National Television System Committee, apresentava problemas de fidelidade das cores, motivo que levou os países europeus a desenvolverem seus próprios sistemas. A França criou o SECAM Sequencial Couleur Avec Mémoire, enquanto que a Alemanha desenvolveu o PAL Phase Alternation Line. Finalmente, em 1974, o Brasil escolheu seu Sistema de TV em cores, o PAL-M, que era compatível com o preto-e-branco já existente no País.

As primeiras transmissões de TV digital terrestre se deram em 1998, nos Estados Unidos. O sistema adotado por esse País foi o Advanced Television Systems Committee - ATSC. Na Europa, foi desenvolvido o Digital Video Broadcasting - DVB e no Japão o Integrated System Digital Broadcasting - ISDB, que somente entrou em operação, naquele País, em 2003.

No Brasil, o processo de tomada de decisão sobre o padrão de televisão digital a ser adotado pelo País foi iniciado em 1999. Desde então, a Agência Nacional de Telecomunicações - ANATEL, em conjunto com outras entidades afins, vem realizando testes com os sistemas de TV digital disponíveis. Em 2003, por meio do Decreto no. 4.901, foi instituído o Sistema Brasileiro de Televisão Digital, que, dentre outros objetivos, deve planejar o processo de transição da televisão analógica para a digital, assim como aprimorar a qualidade de áudio, vídeo e dos serviços oferecidos pelo sistema de televisão atual. Cabe mencionar que, no dia 29 de junho de 2006 foi assinado um decreto que estabelece a escolha do Brasil em adotar como padrão para TV digital a tecnologia desenvolvida no Japão, em conjunto com projetos que foram desenvolvidos por institutos e universidades brasileiras [2].

\subsection{A TELEVISÃo ANALÓGICA}

As transmissões analógicas são caracterizadas por sinais que variam continuamente em função do tempo, podendo apresentar qualquer valor dentre infinitas possibilidades.

$\mathrm{O}$ atual sistema de transmissão terrestre da TV analógica utiliza parte das faixas de radiofreqüência do VHF (Very High Frequency) e UHF (Ultra High Frequency). O VHF é determinado pelo espectro dos $30 \mathrm{MHz}$ aos $300 \mathrm{MHz}$, sendo que, dentre outros serviços, nessa faixa operam os canais de televisão de 2 ao 13. Já o UHF, determinado pelo espectro dos $300 \mathrm{MHz}$ aos $3 \mathrm{GHz}$, contém em parte da sua faixa os canais 14 ao 69. Tanto o VHF quanto o UHF apresentam um espaçamento de $6 \mathrm{MHz}$ para cada canal de TV. No caso do sinal de TV analógico 
brasileiro, a largura da banda do sinal de vídeo é de 4,2 MHz. Neste sinal são enviadas as informações de luminância (brilho), crominância (cor), sinais de sincronismo e o sinal de áudio estéreo e mono [3].

Algumas características definem a imagem projetada em um monitor de televisão, permitindo, assim, sua classificação quanto à resolução. Entre essas características estão: número de linhas horizontais e verticais que formam um quadro; o formato da tela; o número de quadros por segundo; e o tipo de varredura.

O número de quadros por segundo descreve a quantidade de imagens que é apresentada no monitor no intervalo de um segundo. A imagem é formada com o surgimento de linhas horizontais, que são construídas na tela, da esquerda para a direita, processo conhecido como varredura. Após a formação de uma linha, uma nova linha começa a ser varrida logo abaixo, o que determina a formação da imagem de cima para baixo. Quando todas as linhas que compõem um quadro são varridas, essas são apagadas para que o processo seja reiniciado. Em um sistema de 525 linhas são exibidos 30 quadros por segundo, o suficiente para dar a sensação de movimento, já que o cérebro humano não é capaz de notar o apagamento e o surgimento de um quadro [4].

Existem dois tipos de varredura de imagem, a saber: o entrelaçado, que consiste em dividir a imagem em linhas pares e em linhas ímpares e mostrá-las alternadamente em diferentes quadros; e o progressivo, no qual a imagem é formada linha a linha de cima para baixo. O uso ou não de varredura entrelaçada é uma opção entre a ocupação de menor banda, possibilitando um número maior de canais, e uma maior qualidade de imagem [4], [5].

A relação de aspecto define a razão entre largura e altura da tela de uma televisão. Nos sistemas analógicos, a relação de aspecto é de 4:3, enquanto que para o sistema HDTV (High Definition Television) o formato da tela é mais retangular, sendo a relação de aspecto 16:9. A relação de 16:9 foi sugerida pelos EUA, uma vez que essa se encontra próxima das relações presentes nos padrões de cinema.

Os sistemas de televisão analógica existentes se diferenciam, dentre outras características, pelo número de linhas e de quadros que formam a imagem. Nos sistemas SECAM e PAL a imagem é transmitida a uma taxa constante de 25 quadros por segundo e cada quadro é formado por 625 linhas horizontais, com modo de varredura entrelaçado. O sistema NTSC, assim como o PAL-M, apresenta 525 linhas horizontais e utiliza o modo de varredura entrelaçado. Para alcançar a taxa de 30 quadros por segundo é necessária a transmissão de 60 campos, sendo 
30 contendo as linhas pares e 30 contendo as linhas ímpares, atingindo, assim, 60 $\mathrm{Hz}$ de freqüência de varredura, sendo por este motivo adotado por países onde a freqüência da rede elétrica é de $60 \mathrm{~Hz}$ [6].

\subsection{A TELEVISÃO DE ALTA DEFINIÇÃO}

O ganho na definição da imagem foi um grande fator incentivador do desenvolvimento da televisão digital. Para se obter uma imagem com resolução superior à da televisão analógica foi necessário aumentar o número de linhas e de pixels por linha que formam cada quadro da imagem. Isso só foi viável com o advento de técnicas altamente eficientes de compressão de vídeo associadas a técnicas de modulação digital que possibilitaram a transmissão de um sinal digital de alta definição dentro do canal utilizado pela televisão analógica, que no caso do Brasil é de $6 \mathrm{MHz}$.

Além da possibilidade de se transmitir a imagem em alta definição, a televisão digital também permite a diversificação da programação. Por esta razão existem quatro níveis diferentes de resolução: SDTV (Standard Definition Television), LDTV (Low Definition Television), EDTV (Enhanced Definition Television) e HDTV (High Definition Television). A Tabela 2.1 apresenta os dados referentes a cada configuração de imagem:

Tabela 2.1 - Configurações da Qualidade de Imagem da TV Digital [7].

\begin{tabular}{|c|c|c|c|c|}
\hline $\begin{array}{c}\text { Tipo de } \\
\text { Configuração }\end{array}$ & $\begin{array}{c}\text { Número de } \\
\text { Linhas }\end{array}$ & $\begin{array}{c}\text { Número de } \\
\text { Pixels por Linha }\end{array}$ & $\begin{array}{c}\text { Formato de Tela } \\
\text { Utilizado }\end{array}$ & $\begin{array}{c}\text { Volume de bits } \\
\text { Gerado (Mbps) }\end{array}$ \\
\hline \multirow{2}{*}{ HDTV } & 1080 & 1920 & $16: 9$ & 16,5 \\
\cline { 2 - 5 } & 720 & 1280 & $16: 9$ & 10,5 \\
\hline EDTV & 480 & 720 & $16: 9$ & 3,9 \\
\hline SDTV & 480 & 640 & $16: 9$ ou $4: 3$ & 2,8 \\
\hline LDTV & 240 & 320 & $4: 3$ & 0,4 \\
\hline
\end{tabular}

O formato SDTV possui uma definição praticamente igual a definição obtida nos padrões analógicos, tendo sua imagem composta por 525 linhas e varredura entrelaçada com 30 quadros por segundo. A diferença é possuir relação de aspecto 16:9. Por possuir taxa de bits relativamente baixa quando comparado ao HDTV, é possível que em uma faixa de $6 \mathrm{MHz}$ seja possível transmitir até 4 canais de SDTV. 
O HDTV foi inspirado nas telas de cinema. É o formato que apresenta maior resolução e relação de aspecto 16:9 que proporciona ao telespectador maior sensação de movimento, fazendo com que a experiência visual do telespectador tenha mais realidade.

Os dois formatos de HDTV existentes são:

- Sistema de 1125 linhas por quadro, sendo apenas 1080 ativas, entrelaçadas com 30 quadros por segundo. Esse sistema também é chamado de 1080i.

- Sistema de 750 linhas por quadro, sendo 720 linhas ativas, com varredura progressiva e 60 quadros por segundo. Esse sistema também é conhecido como $720 \mathrm{p}$.

Uma opção de resolução intermediária é oferecida pelo formato EDTV, cujo número de linhas é um pouco superior ao SDTV, porém com taxa de bits inferior à encontrada no HDTV. Com essas características, o formato EDTV não ocupa toda a banda disponível [6].

É possível realizar a transmissão de múltiplos canais em diferentes formatos (SDTV, EDTV, LDTV) na banda de $6 \mathrm{MHz}$, porém se o formato escolhido for o HDTV, toda a banda será ocupada para a transmissão de um único canal [6].

A implantação da televisão digital não implica, no entanto, em transmissão em alta definição ou em um número maior de canais. O que deve ser destacado é que com a digitalização da informação o sinal de TV fica compactado, ocupando assim uma largura de banda bem inferior à ocupada pelo sinal analógico. Cabe então ao transmissor a escolha entre melhora da qualidade de áudio e vídeo ou a transmissão de mais canais.

\subsection{PORQUE DIGITALIZAR}

Um dos maiores problemas encontrados na televisão analógica é a interferência que o sinal sofre desde a emissora até o receptor. Uma das modalidades de interferência é a decorrente do multipercurso, em que parte do sinal transmitido chega à antena receptora por um caminho direto, enquanto que outra parte é refletida por obstáculos encontrados e chegam ao receptor com atraso. Várias parcelas do sinal original chegam à casa do telespectador em tempos diferentes e o resultado disso é uma imagem de baixa qualidade, apresentando os chamados "fantasmas". Esse problema é bastante atenuado em alguns sistemas de 
transmissão de televisão digital terrestre que utilizam a técnica de modulação COFDM (Coded Orthogonal Frequency Division Multiplexing) [11].

Outra modalidade de interferência se dá quando o sinal transmitido pela emissora encontra diversos obstáculos até chegar ao receptor, fazendo com que ocorram modificações do seu conteúdo causadas por ruídos oriundos de diversas fontes. O problema se agrava a medida que a televisão encontra-se distante do transmissor, pois a intensidade do sinal que chega até a residência é menor, sendo mais susceptível aos efeitos do ruído.

A transmissão digital minimiza essas distorções, pois seu sinal é representado por valores discretos, o que proporciona maior imunidade ao ruído. Além disso, o sinal digital pode ser regenerado, evitando-se o acúmulo de erros e a perda da informação.

A transmissão digital apresenta técnicas de modulação digitais que possuem maior eficiência espectral, ou seja, um aproveitamento melhor da largura de banda. Seus equipamentos de emissão e recepção apresentam um consumo menor de energia e no processo de digitalização do sinal são utilizadas técnicas de segurança que proporcionam maior proteção e confiabilidade à informação.

No entanto, a transmissão digital apresenta algumas características negativas. Na digitalização do sinal, o processo da amostragem, seguido da quantização e codificação dos valores amostrados introduzem distorção. Como resultado, o sinal gerado após a conversão analógico-digital não é completamente idêntico ao sinal original [9].

Enquanto que em uma transmissão analógica existe uma degradação linear da qualidade de imagem e som quando a distância entre o receptor e transmissor aumenta, nas transmissões digitais o sinal é recebido com qualidade constante, enquanto o campo for suficientemente forte de maneira a existir decodificação quase sem erros. Se o campo do sinal se situar abaixo de um determinado limite mínimo, então ocorre um súbito aumento do número de erros de bit, perda de sincronismo e a conseqüente perda total de som e imagem. Para zonas em que existe uma boa cobertura de emissão este problema não é importante, no entanto, em zonas de fraca cobertura ou onde a geografia é adversa, a recepção torna-se impossível.

Esta situação pode ser evitada com a introdução de hierarquização de dados no codificador de fonte, atribuindo diferentes prioridades aos dados no código de fonte. Isto significa que se a intensidade do campo cair abaixo de um determinado nível, os dados com menor prioridade ficarão inutilizáveis e serão desprezados na decodificação, baixando a qualidade da imagem. Se a intensidade do campo cair 
novamente, os dados com a segunda ordem de prioridade mais baixa serão desprezados e a qualidade da imagem volta a baixar, e assim sucessivamente até ser impossível a decodificação. Deste modo, a imagem terá vários níveis de qualidade perceptíveis pelo utilizador, que serão indicadores das condições de recepção, fazendo com que a imagem não desapareça completamente. [10]

A televisão digital apresenta diversas características que a tornam mais vantajosa que os sistemas de televisão analógica, a saber:

\subsubsection{Alta qualidade de áudio e vídeo}

A TV digital possui grandes vantagens em relação à qualidade da imagem e do som. Essa qualidade vem do desejo de proporcionar ao telespectador uma imagem semelhante à vista em cinemas e um áudio com características encontradas no CD. Associado a isso está o interesse de proporcionar uma maior quantidade de informação, como por exemplo, a transmissão de um jogo em vários ângulos.

A qualidade da imagem da televisão é definida pelo número de linhas e pelo número de pixels que as formam. Atualmente, uma TV analógica se apresenta com 525 linhas e 600 pixels por linha. Na televisão digital de alta definição o número praticamente dobra para 1080 linhas de vídeo e triplica para 1920 pixels por linha, proporcionando um ganho de resolução de quase sete vezes.

A televisão iniciou suas transmissões com o som monofônico (um canal de áudio) e ao longo do tempo evoluiu para o estereofônico (dois canais de áudio esquerdo e direito). A TV digital apresenta seis canais som, além dos dois canais estéreo, as transmissões de alta definição serão acompanhadas por um canal para alto-falante central, mais dois traseiros (surround) e um para baixas-freqüências (sub-woofer). Este é o padrão utilizado atualmente pelos mais avançados equipamentos de som e aparelhos de home-theater disponíveis no mercado [10].

\subsubsection{A interatividade}

A TV digital possibilita a interatividade com o telespectador. Enquanto que na TV analógica a transmissão de dados se dá apenas da emissora de televisão ao telespectador, na TV digital essa relação é incrementada pela existência de um canal de retorno que viabiliza a transmissão do telespectador para as emissoras. 
Na TV digital os aparelhos receptores possuem a capacidade de armazenar dados transmitidos conjuntamente com os sinais de vídeo e som, transformando o receptor de televisão em um equipamento com recursos de processamento de dados próximos aos de um computador. Essa capacidade de armazenamento e processamento digital propicia a utilização de novos serviços. Esses dados armazenados podem ser informações dos mais variados tipos como a ficha técnica de um jogador de futebol, o roteiro da novela, informações históricas e turísticas de determinada locação ou os créditos de determinados programas.

Essa adição de serviços por meio de dados proporciona ganho também em relação ao áudio, com transmissões que incluem tradução ou dublagem em várias línguas diferentes e a possibilidade de selecionar alternativas de áudio à escolha do usuário, como o som de torcida de um determinado time de futebol na transmissão de uma partida. Dessa forma, o usuário pode interagir ao escolher o que é de seu interesse, tendo a possibilidade de armazenar os dados em seu receptor.

Existe também a possibilidade de envio de informação, que pode ser empregada de infinitas maneiras de acordo com a criatividade das emissoras, que podem oferecer serviços como o envio de pedidos de compras, resposta a perguntas em jogos interativos de TV e pagamentos de pay-per-view em cartões de crédito. Será possível disponibilizar serviços que permitam transações bancárias e comércio eletrônico simultaneamente às transmissões de televisão. Outra possibilidade é o acesso à internet convivendo com a transmissão de TV aberta.

O usuário poderá enviar a informação por uma linha telefônica acoplada ao aparelho ou por um sistema de transmissão do próprio aparelho receptor, ainda em fase de desenvolvimento, pelas redes de transmissão de banda larga. A navegação será viabilizada com o controle remoto ou ainda com a utilização de um teclado sem fio [10].

\subsubsection{Acessibilidade}

Com a possibilidade de armazenamento de dados, é possível a gravação de programas. Os aparelhos receptores ou mesmo os conversores, conhecidos como set top box, terão incorporado a eles gravadores digitais que poderão armazenar muitas horas de gravação e permitir que o usuário escolha a hora de assistir ao programa desejado. 
Para fazer uso da nova tecnologia, o telespectador não precisará comprar de imediato uma televisão digital. O set top box é um dispositivo que quando associado à televisão analógica convencional tem a capacidade de realizar a conversão do sinal de digital para analógico. Dessa forma, a televisão analógica poderá continuar operando mesmo que as transmissões sejam somente digitais. No entanto, não haverá melhora na qualidade da imagem caso a televisão não seja compatível com um padrão superior de resolução. A vantagem que será percebida pelo usuário neste caso é o desaparecimento das imagens "fantasma" e dos chuviscos.

Caso o sistema digital forneça algum serviço de interatividade, o set top box deverá ter uma forma de enviar dados do usuário para a emissora ou para um outro destino qualquer. Esse canal de comunicação é denominado canal de retorno ou canal de interatividade. O set top box é dotado de memória, disco, processador, modem e outros dispositivos presentes em microcomputadores, de forma a prover a comunicação com o canal de retorno.

A capacidade de compressão de dados e transmissão da tecnologia digital é tão grande que também será possível a transmissão de um mesmo programa ou filme em horários descontínuos em diversos canais. Essa é uma alternativa para aqueles que não possuem gravadores digitais acoplados em seus receptores, não podendo assim, fazer uso do serviço de gravação [10].

\subsubsection{Capacidade de recepção}

A transmissão digital é flexibilizada pela transmissão hierárquica, que permite ajustar a transmissão às características geográficas de cada área, otimizando a cobertura. A possibilidade de tornar um sinal mais ou menos robusto facilita a recepção em um maior número de pontos de uma área de prestação de serviço, inclusive permitindo que terminais portáteis ou móveis instalados em veículos possam receber essas transmissões [10].

\subsubsection{Canais}

A transmissão digital permitirá a ocupação de canais contíguos $(2,3,4,5,6)$ ao contrário da analógica que necessita de espaçamento entre os canais utilizados para evitar interferência $(2,4,6,8)$. Além disso, o aumento do número de canais 
também será viabilizado pela utilização das faixas de freqüências VHF (canais de 2 a 13) e das freqüências UHF (canais de 14 a 83). Isto significa que em cada área de prestação de serviço poderão estar disponíveis até 82 canais diferentes, dez vezes mais canais do que existem hoje na TV aberta.

Nesse aspecto, cabe mencionar que a ANATEL ainda não determinou o número de canais a serem ocupados nas faixas VHF e UHF, obviamente porque isso determinará as novas regras do mercado de comunicação no País [10].

\subsubsection{Redes de Freqüência Única}

Redes de freqüência única são aquelas em que uma única antena transmissora de grande potência que cobre uma vasta região é substituída por uma rede de transmissoras de pequena potência, operando no mesmo canal, transmitindo o mesmo conteúdo, de forma mais síncrona possível.

Esse tipo de operação apresenta algumas vantagens como a necessidade de menor potência localizada; uma melhor cobertura, especialmente em regiões geograficamente acidentadas; serviço mais confiável em recepção móvel; possibilidade de adoção de uma freqüência única, com abrangência nacional, para cada rede de emissoras; e, no caso de estabelecimento de canal de retorno próprio, a mesma rede que suporta as antenas transmissoras pode ser utilizada para suportar as antenas receptoras da emissora.

As desvantagens identificadas são: a complexidade técnica que teria uma rede de freqüência única em relação a um sistema com antena centralizada e a possibilidade da rede de antenas transmissoras possuir um custo muito maior.

A plataforma ATSC não permite a operação com rede de freqüência única, ao contrário das plataformas DVB e ISDB que abrem essa possibilidade técnica [10].

\subsection{OS PADRÕES DE TV DIGITAL}

Considerando a diversidade de soluções tecnológicas que podem ser adotadas para implementar um sistema de televisão digital, diversas organizações concentraram esforços na especificação de padrões. Como resultado, atualmente existem três padrões mundiais de sistema de televisão digital interativa 
reconhecidos: o ATSC, americano, o DVB, europeu e o ISDB, japonês. Os padrões de TV digital diferem entre si por possuírem características distintas nas camadas que os compõem. A escolha por um padrão implica em aparato técnico determinado por essas características. A Tabela 2.2 resume as características de cada sistema.

Tabela 2.2 Características técnicas dos padrões de televisão digital [11].

\begin{tabular}{|c|c|c|c|c|}
\hline \multicolumn{2}{|c|}{ Camadas } & ATSC & DVB & ISDB \\
\hline \multirow{2}{*}{ Codificação } & Vídeo & \multicolumn{3}{|c|}{ MPEG-2: Vídeo } \\
\hline & Áudio & Dolby AC-3 & MPEG-2: Áudio & MPEG-2: AAC \\
\hline \multicolumn{2}{|c|}{ Multiplexação } & \multicolumn{3}{|c|}{ MPEG-2: Sistemas } \\
\hline \multicolumn{2}{|c|}{ Middleware } & DASE & MHP & ARIB \\
\hline \multirow{3}{*}{ Transmissão } & Terrestre & $8-V S B$ & \multicolumn{2}{|c|}{ COFDM } \\
\hline & Cabo & 64-QAM & 64-QAM & 64-QAM \\
\hline & Satélite & \multicolumn{2}{|c|}{ QPSK } & 8-PSK \\
\hline
\end{tabular}

A observação da Tabela 2.2 nos permite concluir que a diferença entre os padrões está nas camadas de codificação de áudio e na de transmissão o que implica em diferentes características técnicas dos codificadores e decodificadores de áudio e dos moduladores e demoduladores, e na camada de middleware.

Nas seções a seguir serão apresentadas algumas características de cada um dos sistemas de televisão digital existentes.

\subsubsection{ATSC}

Implementado nos Estados Unidos em 1998, o padrão ATSC, que é o mais antigo entre os sistemas de televisão digital, foi desenvolvido visando a transmissão de conteúdo áudio-visual de alta definição (HDTV). Por esse motivo, o sistema fica restrito à transmissão de apenas um programa por canal, ocupando os $6 \mathrm{MHz}$ de banda utilizados pelo sistema de TV analógica americano, o NTSC. Quando o sistema foi desenvolvido não foi levada em consideração a questão da mobilidade e portabilidade da televisão. Dentre os três padrões de televisão analógica este é o único a não disponibilizar este serviço.

Assim como os outros dois padrões de televisão digital, o ATSC utiliza a técnica MPEG-2 para realizar a codificação de vídeo. Essa técnica é utilizada na 
compressão da imagem previamente digitalizada. A taxa de compressão é variável, podendo determinar o nível de desejado, normalmente são utilizados valores em torno de 40:1 (comprimindo a informação em 40 vezes menor que seu tamanho original).

O MPEG-2 possui a característica de comprimir a imagem sem que ocorra perda aparente de qualidade, devido ao fato de ser formado por algoritmos muito eficientes, cujo processamento exige um grande esforço computacional. A compressão utilizada por esse sistema é do tipo multi-frame, significando que na seqüência de quadros que formam a imagem, cada quadro é comparado com o anterior e a diferença entre eles constitui a informação a ser digitalizada.

Para realizar a codificação de áudio, o padrão ATSC adotou o Dolby AC-3, que é um sistema de compressão de áudio que permite comprimir em até 13 vezes a informação sonora. É um sistema fechado (proprietário) desenvolvido pelos laboratórios Dolby dos Estados Unidos e presente nos DVDs [11].

O padrão ATSC é caracterizado por ser um sistema de portadora única, adotando o esquema de modulação de amplitude de 8 níveis discretos, a 8-VSB (Vestigial Side-Band), que é semelhante à modulação utilizada nos sistemas de televisão analógica convencionais [12].

Complexas técnicas de codificação e equalização adaptativa são utilizadas para fazer o sistema mais robusto frente à deteriorização da propagação, como multipercurso, ruído e interferência. A taxa de transmissão de dados deste sistema é de 19,4 Mbps [12].

\subsubsection{DVB}

O DVB é o sistema de televisão digital desenvolvido por um consórcio de países europeus. Entrou em operação em 1998, tendo sido adotado primeiramente pela Inglaterra e posteriormente por outros países do mesmo continente. O sistema DVB apresenta versões para transmissão via satélite, DVB-S; via cabo, DVB-C; terrestre, DVB-T e o DVB-H, que é realiza as transmissãos móveis e portáteis.

Este sistema foi desenvolvido para transmitir com padrão de resolução standard, permitindo a transmissão de vários programas dentro do mesmo canal; porém também tem a opção de transmissão em alta definição (HDTV) e em EDTV [12]. 
O sistema DVB adotou O MPEG-2 para compressão áudio. Esse é um sistema aberto, disponível publicamente, desenvolvido por empresas e entidades de diversos países. Diferente do Dolby AC-3, ele suporta operações de edições, permitindo a realização de gravação doméstica.

Uma das maiores diferenças entre o padrão ATSC e o DVB é a modulação empregada. Enquanto que o ATSC utiliza o 8-VSB, que é um esquema de portadora única, o DVB emprega o COFDM (Coded Orthogonal Frequency Division Multiplexing), que é uma técnica de modulação de múltiplas portadoras. A palavra Coded significa que antes de passar pelo modulador OFDM o sinal é codificado por um corretor de erros que aumenta sua robustez contra interferências [12].

A flexibilidade da técnica COFDM, utilizada na modulação das plataformas DVB e ISDB, possibilita operar em faixas de freqüência com largura de $6 \mathrm{MHz}, 7$ $\mathrm{MHz}$ e $8 \mathrm{MHz}$ constituindo vantagem em relação ao padrão 8-VSB, da plataforma ATSC, que opera somente na canalização de $6 \mathrm{MHz}$.

O padrão DVB desenvolveu também um sistema denominado DVB-H para permitir a transmissão de sinal associada à mobilidade e à portabilidade. O DVB-H supera duas limitações do padrão de DVB-T: reduz o consumo de potência de bateria dos receptores e melhora a robustez em ambientes muito difíceis de recepção para equipamentos portáteis com antena interna [13].

Assim como o DVB-T, o DVB-H pode ser usado em ambientes com canais de 6, 7 e $8 \mathrm{MHz}$. No entanto, a opção de $5 \mathrm{MHz}$ também é especificada para ambientes que não sejam de transmissão. Um dos requisitos iniciais principais, e recurso importante do DVB-H, é que ele pode coexistir com o DVB-T em um mesmo multiplexador [13].

A Figura 2.1 ilustra a rede de funcionamento do DVB-H. 


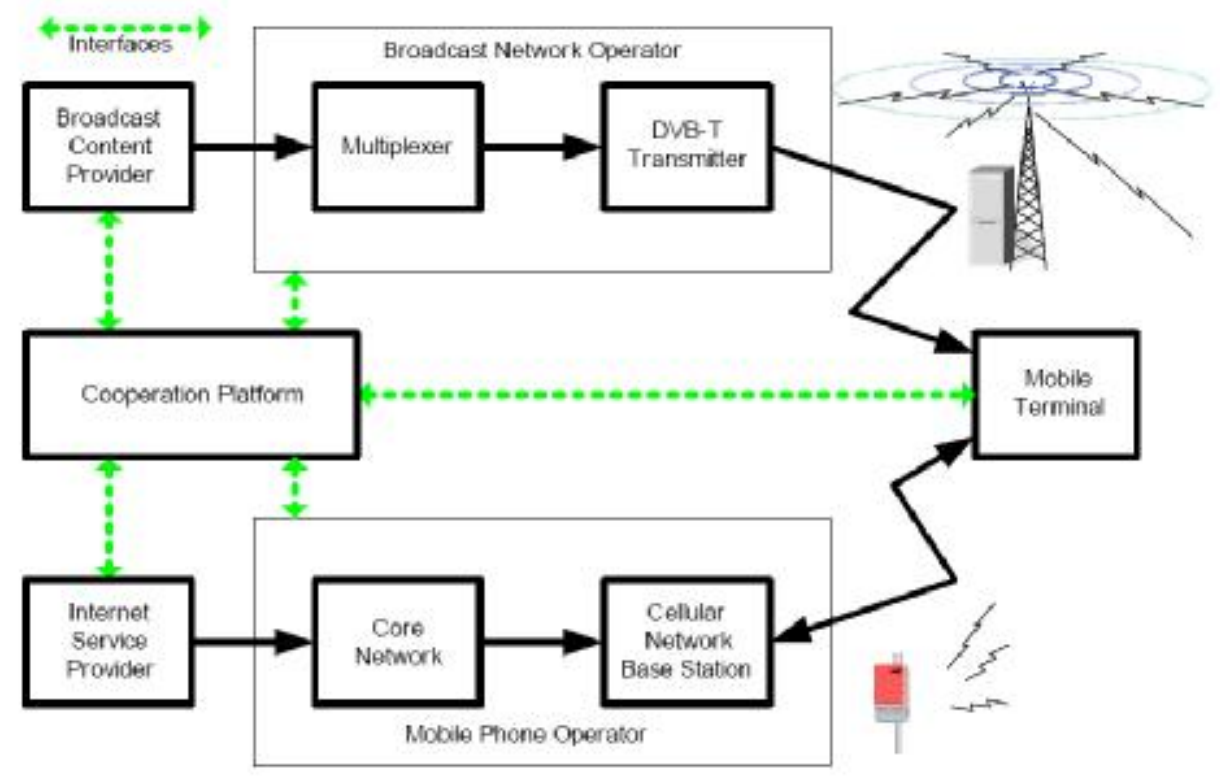

Figura 2.1- Rede de funcionamento do DVB-H [13].

\subsubsection{ISDB}

O sistema japonês entrou em funcionamento em 2003 e é uma evolução do sistema DVB. Apresenta versões para transmissão via satélite, ISDB-S; via cabo, ISDB-C e terrestre, ISDB-T. Assim como o DVB, utiliza o sistema de transmissão com múltiplas portadoras (OFDM), mas com uma inovação: a segmentação de banda. Os $6 \mathrm{MHz}$ de banda do canal são divididos em 13 segmentos, cada um com aproximadamente $430 \mathrm{kHz}$ [12].

Uma das preocupações dos desenvolvedores do sistema japonês foi criar um sistema que além de permitir a transmissão em alta definição, possibilitasse ainda a mobilidade e a portabilidade. Comparado com o DVB, o ISDB é mais eficiente na transmissão de sinal digital para recepção móvel, pois não requer mais banda para realizar este serviço. A informação transmitida para a recepção móvel se restringe a um dos segmentos ISDB e por este motivo consegue ser demodulado por um receptor de banda estreita [12].

O sistema ISDB também adotou um sistema MPEG de codificação de áudio, porém, a versão escolhida, a AAC, é mais avançada que a adotado pelo DVB. Por esta razão pode-se afirmar que o ISDB tem o sistema de codificação de áudio mais eficiente entre os três sistemas de televisão digital [12].

Entre as três plataformas, o ISDB difere da ATSC e da DVB por ter sido implementado para múltiplas aplicações e não apenas para o serviço de televisão. A 
segmentação de banda é estruturada para obter a máxima racionalização da utilização do canal. Orientado por este princípio, no ISDB, em tese, um canal de 6 $\mathrm{MHz}$ poderia ser dividido entre 13 serviços ou emissoras diferentes. O ISDB também reserva parte de cada um dos segmentos que dividem a freqüência utilizada para operar como se fosse um canal auxiliar para uso genérico de transporte de dados.

Outro diferencial da plataforma ISDB é a possibilidade de utilizar um dos segmentos de freqüência para transmitir para receptores de faixa estreita, possibilitando, por exemplo, que receptores de rádio digital sejam capazes de decodificar o áudio de um programa de televisão. No que se refere à segmentação de banda, portanto, a implementação do padrão COFDM, da plataforma ISDB, leva vantagem em relação às plataformas DVB e ATSC.

\subsubsection{Soluções Híbridas}

A análise das experiências de diversos países revela a possibilidade de soluções híbridas, através da adoção de elementos de diferentes plataformas de TV digital. Na Austrália, por exemplo, optou-se pela plataforma DVB, mas adotou-se o padrão Dolby AC-3 para a codificação de áudio ao invés do padrão MPEG-2. Mesmo os Estados Unidos estão convivendo com soluções híbridas. O grupo norteamericano Sinclair Broadcast Group pleiteou e obteve autorização do FCC (Federal Communications Commission), o órgão regulador deste País, para utilizar o padrão COFDM para a transmissão de televisão digital, embora operando com a plataforma ATSC [10].

As três plataformas, como se pode observar, não são sistemas completamente fechados e os padrões utilizados não apresentam incompatibilidades intransponíveis entre si. A escolha da plataforma e dos padrões de processamento técnico das três camadas, portanto, não pode ser tratada como uma solução absoluta, pois está sujeita a escolhas possíveis que dependem do projeto e dos objetivos de cada País [10].

\subsection{O SISTEMA BRASILEIRO DE TV DIGITAL}

Os estudos para a implantação da tecnologia de televisão digital no Brasil começaram em 1994, sob a responsabilidade da Associação Brasileira das 
Emissoras de Rádio e Televisão (ABERT) e da Sociedade Brasileira de Engenharia de Televisão e Telecomunicações (SET). Em 1999, a ANATEL passou a realizar testes com os sistemas de TV digital existentes, buscando o modelo que atenda as necessidades do País.

Em razão do sistema brasileiro de televisão aberta ser uma importante fonte de disseminação de informações, entretenimento e da responsabilidade em relação à cultura nacional e à própria cidadania, o Governo publicou o Decreto 4.901, de 26 de novembro de 2003, em que instituiu o Sistema Brasileiro de Televisão Digital (SBTVD). Nesse decreto o governo demonstra o interesse em realizar a inclusão digital da população com a implementação da televisão digital.

Para realizar a escolha do sistema de televisão digital que será adotado no País, o governo priorizou um modelo que seja voltado para o cidadão brasileiro de baixa renda, de forma que seja possível, ao mesmo tempo, incluir socialmente as camadas mais desfavorecidas, capacitar e formar novas gerações de pesquisadores, prover acesso à Internet e, ainda, entretenimento.

Após a criação do SBTVD, o governo criou diversos grupos de pesquisa em institutos de todo o País. A PUC/RS criou o Sistema OFDM com Redução de Complexidade por Equalização Robusta, o SORCER, que é um sistema de modulação que proporciona alta eficiência espectral, receptores de baixo custo e transmissão móvel em alta definição. Vários aplicativos da televisão digital para a saúde, educação e comunicação foram desenvolvidos em várias faculdades do País. A UFPB criou o middleware FlexTV, que é uma evolução do utilizado no sistema DVB [14].

Por ser uma decisão com grandes impactos sociais e econômicos, o governo realizou vários estudos e debates, e fez a escolha pelo padrão japonês. O Ministro das Comunicações, Hélio Costa, afirmou que o processo de implantação dos serviços de TV digital também fará uso das tecnologias que foram desenvolvidas pelos institutos e universidades brasileiras. 


\section{ELEMENTOS BÁSICOS DE UM SISTEMA DE TELEVISÃO DIGITAL}

\subsection{INTRODUÇÃO}

Atualmente existem três padrões disponíveis de televisão digital. Esses padrões seguem um modelo de referência apresentado pela União Internacional de Telecomunicações (ITU), que define as funcionalidades do sistema em três camadas principais. A Figura 3.1 ilustra esse modelo:

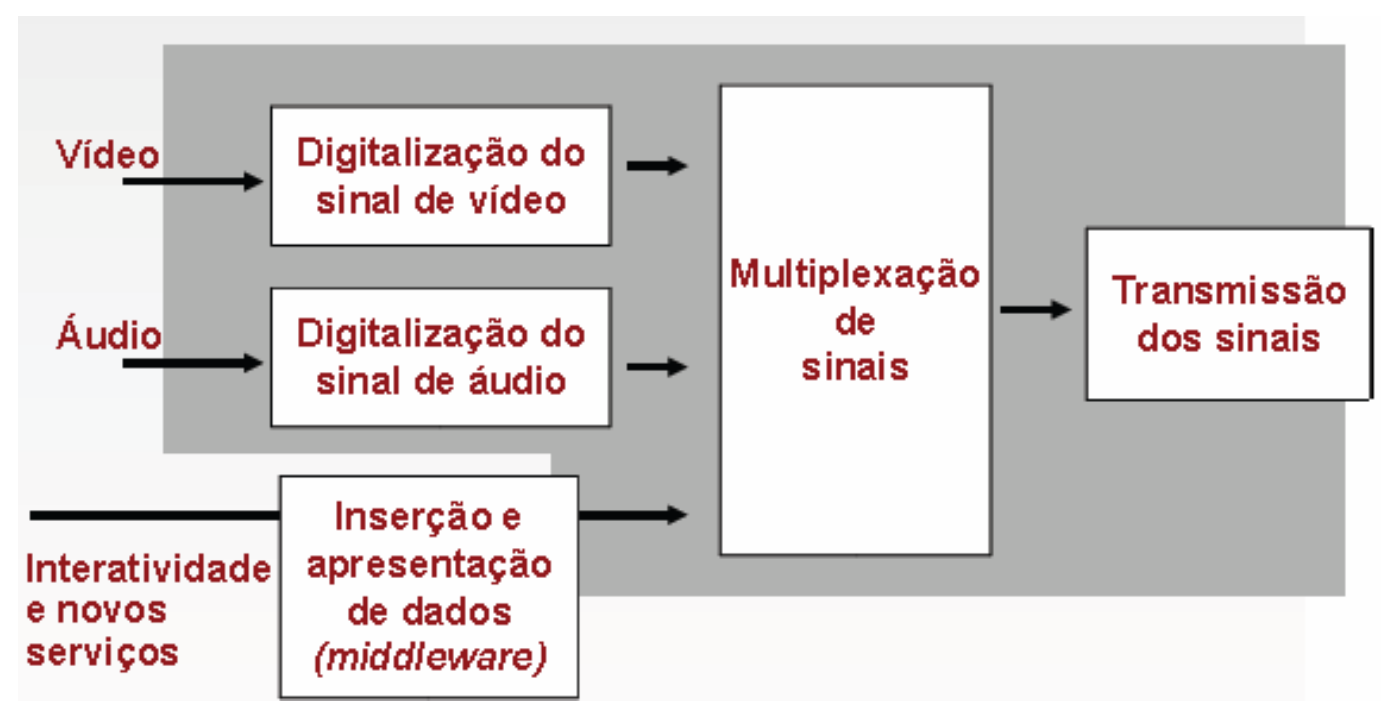

Figura 3.1 Modelo de referência da ITU para camadas de um sistema de televisão digital [15]. 
As camadas estabelecidas nesse modelo podem ser definidas da seguinte forma:

- Camada de codificação do sinal-fonte - etapa em que ocorre a conversão e compressão dos sinais de áudio e vídeo em feixes digitais (fluxos elementares de informação) [16].

- Middleware - é uma camada de software que facilita o desenvolvimento e a execução de aplicações interativas. Dessa forma os desenvolvedores de aplicações deixam de se preocupar com os protocolos existentes entre a camada de hardware e a dos softwares aplicativos. A maioria dos produtos de middleware suporta máquinas virtuais HTML e JavaScript [16].

- Camada de multiplexação - nesta etapa ocorre a combinação dos fluxos elementares (áudio, vídeo e dados), formando um feixe digital único. Também são inseridas informações que irão permitir a sincronização de diferentes mídias e a recuperação da base de tempo dos programas no receptor pela inserção de informações de acesso condicional e pelo empacotamento dos dados em pacotes de tamanho fixo [16].

- Camada de codificação do canal e modulação - nessa etapa ocorre a conversão do feixe digital multiplexado em um sinal que pode ser transmitido por um meio físico. A codificação do canal é responsável pela correção de erros introduzidos pelo canal [16].

\subsection{CAMADA DE CODIFICAÇÃO DO SINAL-FONTE}

Essa camada está dividida em duas etapas: a codificação do sinal de vídeo e a codificação do sinal de áudio.

\subsubsection{Codificação do sinal de vídeo}

Em razão da elevada taxa de bits de um sinal de vídeo digital de alta defnição, que pode superar $1 \mathrm{Gbps}$, tem-se a impossibilidade de sua transmissão na largura de banda de $6 \mathrm{MHz}$, destinada aos canais de televisão em alguns países, entre eles o Brasil. Os sistemas de TV digital desenvolvidos, ATSC, DVB-T e ISDB$\mathrm{T}$, fazem uso de processos de modulação que permitem transmitir em taxas de até $20 \mathrm{Mbps}$ na banda de $6 \mathrm{MHz}$. Para que essa imcompatibilidade fosse resolvida, viu-se 
a necessidade de reduzir de alguma maneira a taxa de bits de um programa de televisão. Os três sistemas de TV digital utilizam o mesmo método de compressão de vídeo, o MPEG2(Moving Picture Expert Group 2).

O diagrama ilustrado na Figura 3.2 apresenta o princípio básico do processo MPEG2. Nesse processo temos a utilização de técnicas que comprimem o sinal de vídeo reduzindo a qualidade da imagem de forma imperceptível e técnicas que não afetam a qualidade da imagem, como o mecanismo de eliminação das redundâncias na informação.

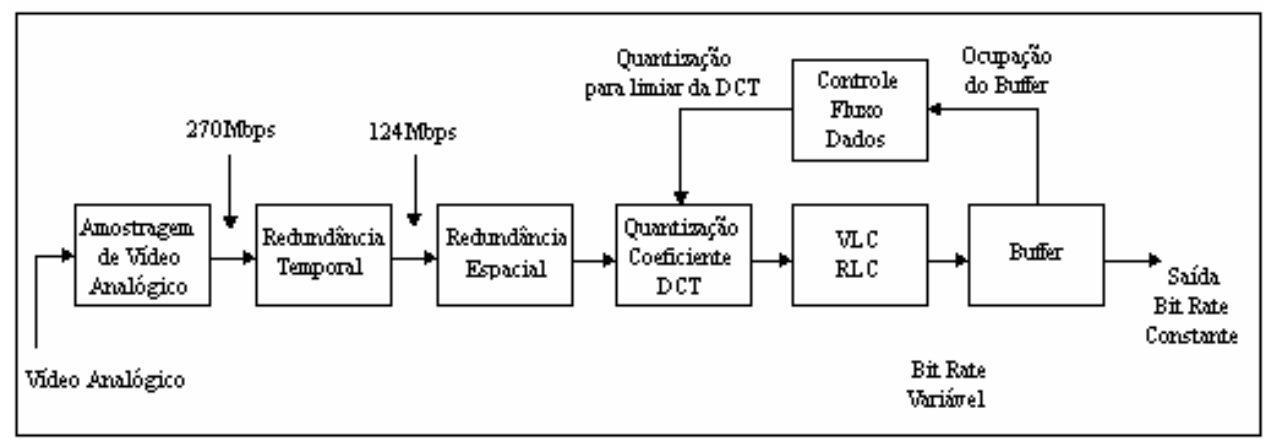

Figura 3.2 Diagrama em blocos da codificação de vídeo MPEG2 [5].

Um sistema de televisão em cores é composto pela combinação das três cores primárias: Red $(\mathrm{R})$, Green $(\mathrm{G})$ e Blue(B). Na câmera de TV, existem filtros e espelhos que separam essas três componentes e as enviam para diferentes tubos, onde ocorrem os processos de varredura para conversão da informação luminosa em sinal elétrico $\left(E_{R}, E_{G}\right.$ e $\left.E_{B}\right)[5]$.

No esquema apresentado na Figura 3.3, essas componentes inicialmente passam por um processo de correção denominado correção gama que compensa as distorções introduzidas pelos tubos tanto na geração do sinal quanto na reprodução da imagem. Em seguida, ocorre a filtragem dos sinais elétricos de forma a limitar seus espectros, evitando, assim, o efeito de aliasing (sobreposição das componentes espectrais) no processo de amostragem [5]. 


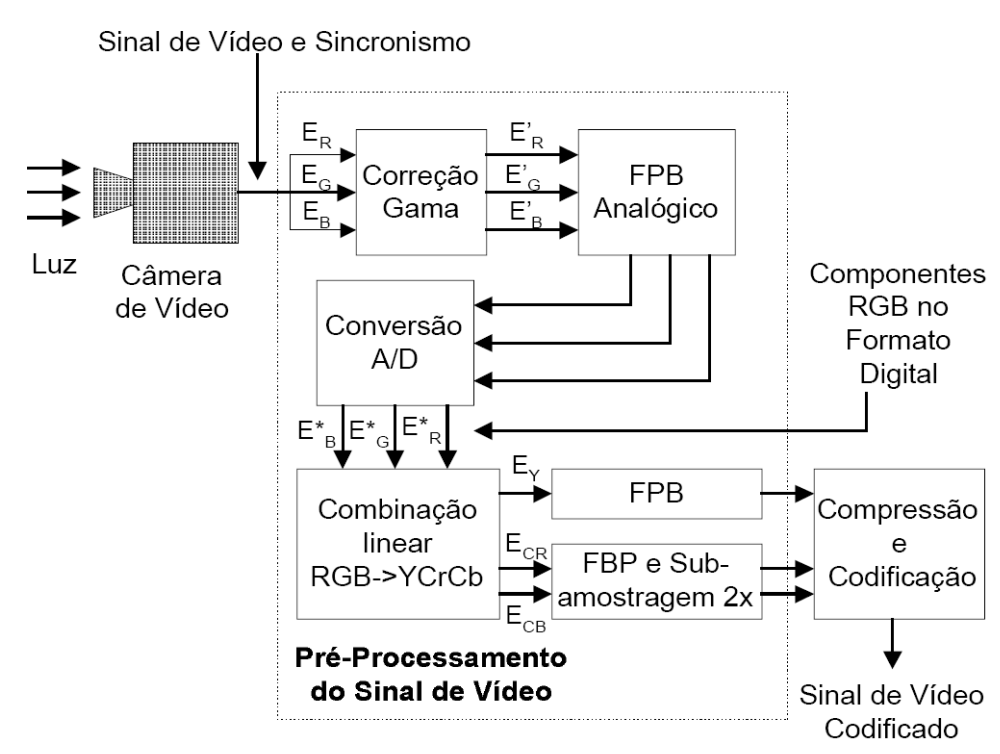

Figura 3.3 - Etapa de amostragem e digitalização do sinal [5].

O processo de amostragem tem como finalidade a conversão do sinal analógico para digital. Nesse processo, tem-se uma freqüência mínima de amostragem por segundo, obedecendo ao teorema de Nyquist (onde a freqüência de amostragem deve ser maior que duas vezes a máxima freqüência do sinal amostrado) [5].

Após o processo de amostragem, cada amostra é quantizada, obtendo como resultado sinais discretos no tempo. Em seguida, esses sinais passam por uma transformação linear que os converte em duas componentes de crominância (sinais de diferença de cor), $E_{C R}$ e $E_{C B}$ e uma componente de luminância (contém informação do brilho da imagem), EY. O sistema visual humano é mais sensível às variações de luminância do que de crominância, sendo assim, algumas amostras de sinais de crominância poderão ser desprezadas no processo de sub-amostragem, proporcionando, para etapas posteriores, um aumento na compressão, sem que ocorra prejuízo na qualidade da imagem [5].

A redundância temporal consiste no aproveitamento da similaridade existente entre os conjuntos de quadros que, em seqüência, formam uma imagem dinâmica. As imagens são separadas em quadros de 16X16 pixels e baseada na semelhança entre um quadro e os posteriores, para cada um deles, um vetor de movimento é estimado, codificado e transmitido. Para que a qualidade da imagem não seja comprometida, o erro de estimação, definido como a diferença entre um quadro e sua estimação, também é transmitido. A esse processo é dado o nome de predição por compensação de movimento [17]. 
Para garantir uma correta estimação e compensação de movimento, o algoritmo do MPEG2 estabelece sua seqüência com três tipos de quadro: Interframe (I), que são quadros em que a imagem foi codificada inteiramente, não possuindo nenhuma predição temporal; Bidirectional Predicted Frames, que são quadros intermediários, possuindo a informação das diferenças entre o quadro atual e anterior e o quadro atual e o posterior e o Forward Predicted Frames, que são quadros baseados no quadro anterior, podem ser usados como referência para os próximos quadros e possuem alta compressão [17].

A redundância espacial refere-se à semelhança dos pixels adjacentes de uma imagem. Partes da imagem que não possuem muita importância, como o chamado pano de fundo, podem sofrer perdas sem significância para a qualidade da imagem [17].

Tendo como base o conceito de que a eliminação de altas freqüências não causa degradações perceptíveis na imagem, o algoritmo do MPEG2 converte a amplitude espacial da imagem em freqüência espacial por meio da DCT (Transformada Discreta de Co-seno). Esse processo tem o objetivo de concentrar a energia em poucos coeficientes [17].

O processo de aplicação da DCT é feito após a divisão da imagem em blocos de $8 \times 8$ pixels, resultando em coeficientes que representam a freqüência espacial. Dependendo do número de detalhes contidos no bloco original, boa parte dos coeficientes assumirá valores próximos de zero, sendo esses valores passíveis de serem descartados. Esse processo reduz consideravelmente a taxa de informação a ser transmitida, sendo completamente reversível e é uma compressão sem perdas até o momento em que os coeficientes de baixo valor são descartados .

Os coeficientes da DCT são quantizados para reduzir sua amplitude e aumentar o número de coeficientes iguais a zero, sendo possível descartar mais informações que são visualmente insignificantes. Durante todo o processo de codificação do MPEG2, esse é o estágio em que ocorrem maiores perdas [17].

Após o sinal de vídeo passar pela quantização, ele é codificado pelo processo denominado RLC (Run Lenght Code), que agrupa as informações repetidas, em conjunto com o processo VLC (Variable Lenght Code), que atribui símbolos de menor comprimento às informações repetidas. Dessa forma, quanto maior o número de elementos repetidos, maior é a eficiência da codificação.

O buffer é o dispositivo destinado a controlar o fluxo de dados, garantindo que a taxa de bits na saída do compressor seja sempre constante. O controle dessa taxa é feito durante o processo de quantização. 


\subsubsection{Codificação de áudio}

Como mencionado anteriormente, o parâmetro de qualidade buscado para o sinal de áudio nos sistemas de TV digital é apresentado no CD. O codificador de áudio MPEG, aproveitando que o ouvido humano possui a característica de não ser um aparelho perfeito para captar sons, consegue reduzir a taxa de dados de um CD em aproximadamente doze vezes, sem perda significativa da qualidade.

O MPEG2 Áudio foi desenvolvido com base no MPEG1, proporcionando maior qualidade e maior eficiência, oferecendo os requisitos necessários para as redes digitais. Além do suporte para canais monofônicos e estéreofônicos, existentes no MPEG1, O MPEG2 possibilita a existência dos seis canais que formam a configuração 5.1 (canais de áudio esquerdo, direito, no centro, dois canais de surround e um para baixas-freqüências, chamado de sub-woofer). Essa configuração resulta em um som com o mesmo desempenho que se tem em cinemas, permitindo a reprodução de um som estereofônico mais realista. Existe ainda a possibilidade do uso de outros canais para transmissão em outros idiomas, aumentando o poder de escolha do telespectador.

Para efetuar a compressão de áudio, existem duas alternativas: a primeira consiste em reduzir a freqüência de amostragem, e a segunda, em reduzir a resolução da amostra. Para se obter uma boa qualidade, não se pode fazer grandes alterações na freqüência de amostragem em razão do valor máximo de freqüência captado pelo ouvido humano $(20 \mathrm{kHz})$.

Obedecendo ao critério de Nyquist, é necessário que o sinal de áudio seja amostrado pelo menos 44.000 vezes por segundo, já que a faixa de freqüência audível pelo ouvido humano é de $16 \mathrm{~Hz}$ a $20 \mathrm{kHz}$. Fazendo o uso de um código de 16 bits tem-se uma taxa de 704kbps. Já para a transmissão de música estéreo, em que são produzidas duas vezes a taxa de bits do canal mono, tem-se como resultado uma taxa de 1,4 Mbps, que precisa passar por um processo de compressão para possibilitar a sua transmissão.

A razão da escolha do código de 16 bits deve-se ao fato de obter uma melhor relação sinal/ruído. Para cada bit que se adiciona ao código há uma melhoria de 6 $\mathrm{dB}$ na relação sinal-ruído. Ao se utilizar código com um número menor de bits por amostra, pode-se ainda perceber ruído de fundo nos momentos de silêncio de música. Entretanto, para a codificação com 16 bits, se o nível do som é elevado, o ruído não é perceptível, visto que qualquer ação acústica que ocorra ao mesmo 
tempo, mas com intensidade menor, não será ouvido, pois este será mascarado pelo som principal e de maior intensidade. Esse efeito é chamado de Efeito Máscara (masking threshold) [17].

\subsection{CAMADA DE MIDDLEWARE}

Os receptores de televisão digital, os set top boxes, possuem diferentes características, tais como capacidade de processamento e de armazenamento, velocidade de comunicação, além de vários sistemas operacionais que podem ser adotados dependendo da escolha de cada fabricante. Diante de toda essa variedade de hardware e software, os desenvolvedores de aplicações de televisão digital seriam obrigados a desenvolver versões específicas de cada uma das aplicações para cada combinação de hardware e software. Obviamente isso inviabilizaria a produção em larga escala, tornando o desenvolvimento de aplicações para a TV digital uma atividade ineficiente e de altíssimo custo.

Para resolver esse problema e possibilitar a consolidação do mercado de TV digital interativa, os fabricantes de conteúdo decidiram adotar uma camada de software capaz de prover uma interface única à camada de aplicação através de uma Application Programming Interface (API), essa camada foi denominada middleware[16] .

O middleware funciona como uma API genérica, exercendo a função do sistema operacional de cada set top box. A camada de middleware proporciona um serviço padronizado às aplicações, resolvendo o problema de incompatibilidade com os diversos tipos de hardware e de sistemas operacionais.

Como conseqüência, sem qualquer tipo de modificação, as aplicações podem ser diretamente executadas em qualquer receptor que suporte o middleware adotado no desenvolvimento das mesmas.

Visando usufruir dos benefícios proporcionados pela camada de middleware, vários órgãos de padronização se dedicaram a especificar padrões de middleware. No entanto, alguns órgãos publicaram seus padrões de forma independente, e por esta razão, as aplicações são independentes do set top box, porém dependem do padrão de middleware [16].

Atualmente, existem três padrões de middleware para TV digital: MHP Multimedia Home Plataform (ETSI, 2003c), DASE - DTV Application Software Environment (ATSC, 2003) e ARIB - Association of Radio Industries and Businesses 
(ARIB, 2002). Vale ressaltar que, apesar das aplicações serem compatíveis entre diferentes plataformas de hardware e sistema operacional, elas são dependentes do middleware adotado, ou seja, uma aplicação desenvolvida para o middleware DASE não é compatível com o MHP e o ARIB [16].

\subsection{CAMADA DE TRANSPORTE}

A camada de transporte recebe as seqüências de bits geradas pelos codificadores de áudio, vídeo e de dados auxiliares e realiza a multiplexação dos mesmos, produzindo, em sua saída, uma única seqüência de pacotes, sendo utilizado o padrão MPEG-2 TS (Transport Streams) para realizar esta tarefa.

Existem duas maneiras para se realizar a codificação dos pacotes: o fluxo de programa ou o fluxo de transporte. No fluxo programa os pacotes gerados possuem tamanho variável e geralmente grande. Este tipo de fluxo é utilizado em sistemas de transmissão com baixa probabilidade de ocorrência de erros, o que não é o caso de sistemas de televisão.

No fluxo transporte os pacotes possuem tamanho fixo de 188 bytes, sendo mais adequados para tratamento de erros. O tamanho reduzido de 188 bytes do pacote é proposital, pois no caso de ocorrer perda devido a interferências externas, a re-sincronização do vídeo ou do áudio não será seriamente afetada.

A seqüência de pacotes é demultiplexada no receptor, onde as seqüências de bits são reconstruídas e levadas até seus respectivos decodificadores. A sincronização do receptor e a detecção de erros só são possíveis devido à existência de dados no cabeçalho de cada pacote de bits.

Antes de ocorrer a multiplexação e a organização dos pacotes, as seqüências de bits podem ser organizados em Packetized Elementary Streams (segmentos PES), que têm como objetivo possibilitar a sincronização das seqüências elementares de bits de cada programa. As seqüências de bits de áudio e vídeo são sempre organizados em segmentos PES. O processo pode se dar no sistema de multiplexação ou no próprio codificador de bits.

A multiplexação na camada de transporte é realizada em duas etapas. Primeiramente, as seqüências de bits geradas pelos codificadores são multiplexadas entre si juntamente com uma seqüência de bits de controle, que recebe o nome de Elementary Stream Map. O resultado dessa multiplexação de bits forma um 
programa de televisão. A Figura 3.4 ilustra a multiplexação nesse nível, supondo que as seqüências elementares já estão na forma de pacotes de transporte.

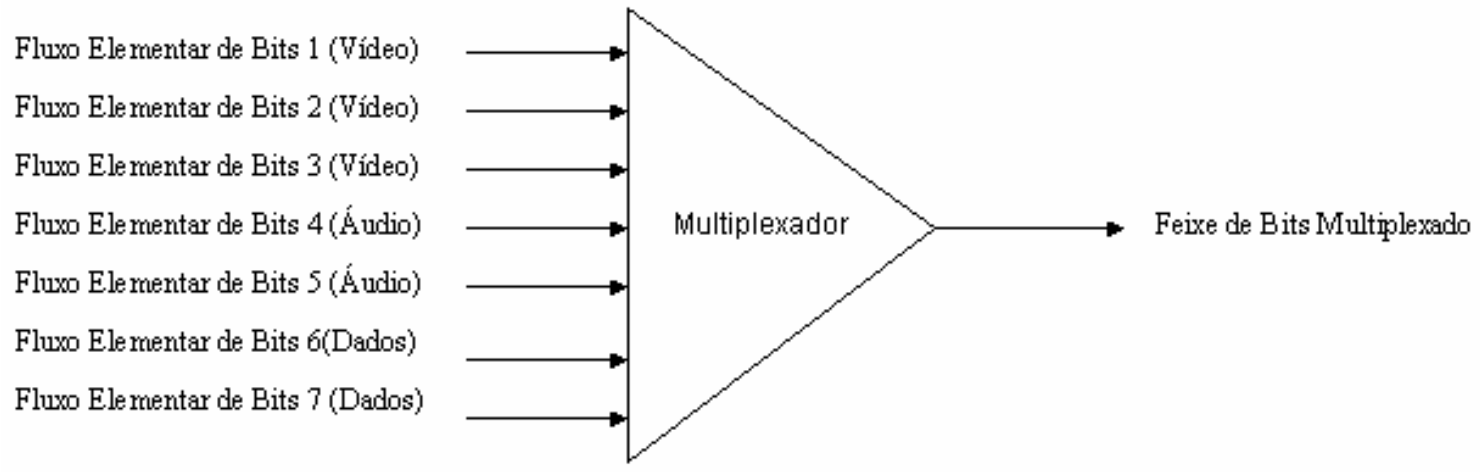

Figura 3.4 Esquema de multiplexação [12].

Na segunda etapa da multiplexação os programas são multiplexados entre si e com uma seqüência de bits de controle de nível hierárquico mais elevado, conhecida com Program Stream Map.

Os programas, por sua vez, são multiplexados entre si e com uma seqüência de controle de mais alto nível, a Program Stream Map, formando, então, a seqüência de transporte do sistema [12].

\subsection{CAMADA DE CODIFICAÇÃO DO CANAL E MODULAÇÃO}

O modulador de um sistema de televisão digital é composto basicamente por três blocos funcionais: o codificador, o estruturador de quadro e o modulador. $\mathrm{O}$ codificador tem como função fazer com que o sinal digitalizado seja robusto a interferências. O estruturador de quadro monta a estrutura de quadro do sinal digital e acrescenta informações de sincronismo e controle ao mesmo. O modulador, que dependendo do sistema de TV digital pode ser COFDM ou 8VSB, efetua a modulação da portadora e desloca o sinal modulado para uma freqüência intermediária $(\mathrm{FI})$. Ocorre então uma etapa de conversão de freqüência, em que o sinal é transferido da FI para a freqüência do canal de TV desejado.

Uma grande diferença entre os padrões de televisão digital é o sistema de modulação adotado por cada um deles. Enquanto o padrão ATSC adotou o esquema de modulação 8VSB (Vestigial Side Band), que é semelhante ao utilizado 
nos sistemas de televisão analógica, os padrões DVB-T e ISDB-T adotaram o COFDM (Coded Orthogonal Frequency Division Multiplexing) [12].

\subsubsection{Modulação 8VSB}

A 8VSB é um esquema de modulação de amplitude de 8 níveis que tem como principal característica ser um sistema de portadora única. O sinal modulado com a técnica 8VSB ocupa uma largura de banda de $6 \mathrm{MHz}$, a mesma utilizada no sistema analógico. A Figura 3.5 ilustra o processo de modulação 8VSB.

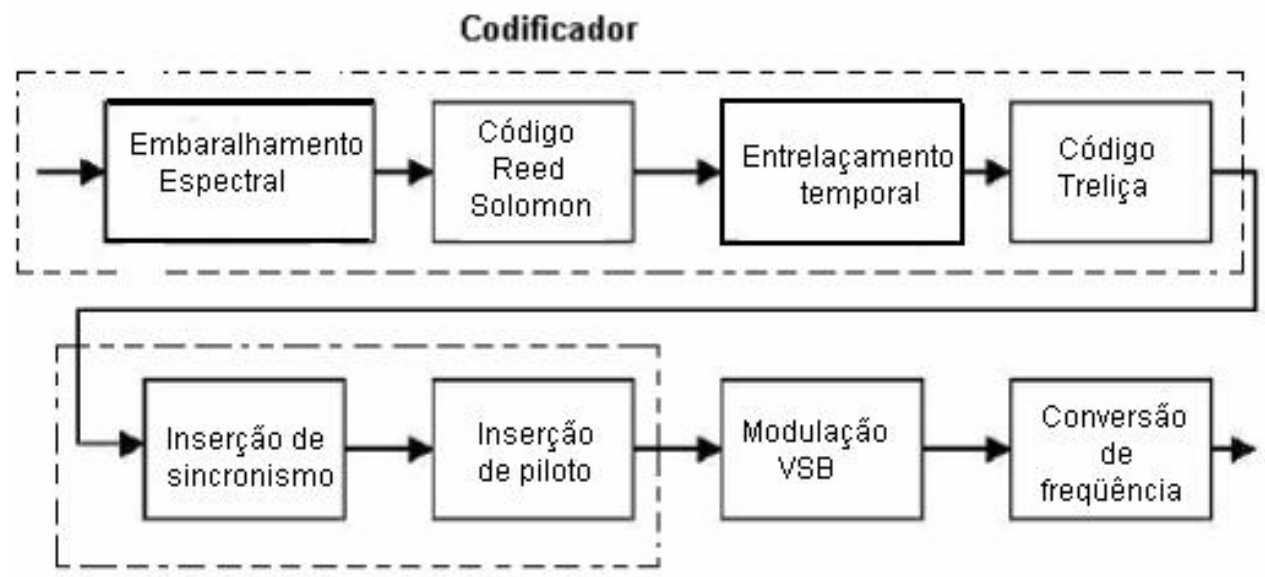

Estruturador de Quadro

Figura 3.5 - Processo de modulação 8VSB.

O Codificador é constituído pelos blocos de Embaralhamento Espectral, Codificador Reed Solomon, Entrelaçamento Temporal e Codificador de Treliça (Trellis Encoder).

A função do Embaralhamento Espectral é fazer com que a distribuição de bytes dentro de cada pacote de dados seja aleatória. Esse procedimento se faz necessário para evitar a concentração de energia no espectro do sinal modulado, que ocorre devido à repetição de padrões de dados. Caso este bloco não existisse, o sinal modulado poderia ter sua imunidade às interferências comprometida e a possibilidade de interferência entre canais de TV seria maior.

O Codificador Reed Solomon é um Forward Error Correction Code (FEC), tendo como função permitir que o receptor seja capaz de detectar e corrigir erros no sinal digital demodulado. Este codificador acrescenta 20 bytes de redundância para cada 187 bytes, os 207 bytes totais formam um segmento. O receptor é capaz de 
detectar e corrigir até 10 bytes errados em cada segmento. Com o acréscimo de bytes, a taxa de bits do sinal aumenta, passando de 19,39 Mbps para 21,45 Mbps [12].

O próximo bloco é o do embaralhamento temporal (Data Interleaver), que tem a função de embaralhar os dados do sinal de entrada. Esse embaralhamento evita que interferências do tipo burst (ruído impulsivo) danifiquem vários bits seguidos. $O$ decodificador Reed Solomon tem sua eficiência diminuída quando os erros aparecem todos agrupados, então o embaralhamento de dados permite um funcionamento eficaz deste decodificador.

No último estágio do codificador é inserido um segundo código corretor de erros, o codificador de Treliça, que age de forma complementar ao codificador Reed Solomon, tendo como objetivo detectar e corrigir erros gerados por interferências no canal de televisão. Este codificador é do tipo convolucional e gera três bits na sua saída a cada dois bits introduzidos na sua entrada, sendo que o primeiro bit de entrada é copiado na saída. O segundo bit de entrada dá origem a dois bits na saída, utilizando-se um codificador de razão 1/2. Quatro $\left(2^{2}\right)$ possibilidades de entrada dão origem, então, a oito $\left(2^{3}\right)$ diferentes estados na saída, o codificador neste caso é de razão $2 / 3$. Cada um dos oito estados possíveis representam um estado diferente da amplitude do sinal modulado [12].

No segundo macro-bloco, o estruturador de quadro, ocorre a inserção de bits adicionais de sincronismo e o sinal digital é convertido, símbolo a símbolo, em um dos 8 diferentes níveis de tensão. Um pequeno sinal DC é inserido com o objetivo de gerar um piloto de mesma fase e freqüência da onda portadora, que é suprimida no estágio seguinte durante a modulação. O piloto faz com que seja possível detectar e demodular o sinal sem que ocorram grandes perdas de potência.

No estágio do modulador ocorre a modulação de uma portadora na freqüência intermediária, sendo a modulação de amplitude com portadora suprimida. $O$ sinal resultante passa pelo misturador que muda a freqüência do sinal da FI para a freqüência da emissora de televisão.

\subsubsection{Modulação COFDM}

A técnica de modulação Coded Orthogonal Frequency Division Multiplexing (COFDM) se diferencia da modulação 8VSB por ser um esquema de múltiplas portadoras, que são moduladas e transmitidas simultaneamente. A palavra Coded significa que antes de ser modulado utilizando-se a técnica OFDM o sinal passa por 
um esquema de codificação de canal, que proporciona maior robustez às interferências.

No sistema COFDM cada portadora é modulada individualmente e o sistema se mostra bastante flexível ao oferecer algumas possibilidades de esquema de modulação como o QPSK (Quadrature Phase Shift Keying), 16QAM (Quadrature Amplitude Modulation) ou 64QAM.

Em sistemas de portadora única os símbolos são transmitidos serialmente, o que significa que o espectro de cada símbolo ocupa toda a largura de banda do canal durante o tempo de sua transmissão. Isso significa que a janela temporal para cada símbolo é muito pequena para altas taxas de transmissão.

Nos sistemas de múltiplas portadoras, como o COFDM, os símbolos passam por um conversor série-paralelo, sendo divididos em um número de seqüências equivalente à quantidade de portadoras que serão moduladas. Isso faz com que o tempo de duração de cada símbolo seja bastante superior aos dos sistemas de portadora única.

Para que uma portadora não cause interferência a uma outra de freqüência adjacente, as suas freqüências são escolhidas de forma que estas sejam ortogonais entre si no intervalo de duração de cada símbolo, esta é a razão do nome Orthogonal Frequency Division Multiplexing. A ortogonalidade entre as portadoras, ilustrada na Figura 3.6, faz com que não seja necessário um intervalo de guarda entre cada uma delas, permitindo inclusive que seus espectros estejam sobrepostos. Por esta razão a técnica OFDM apresenta maior eficiência espectral que a Frequency Division Multiplexing (FDM) convencional.

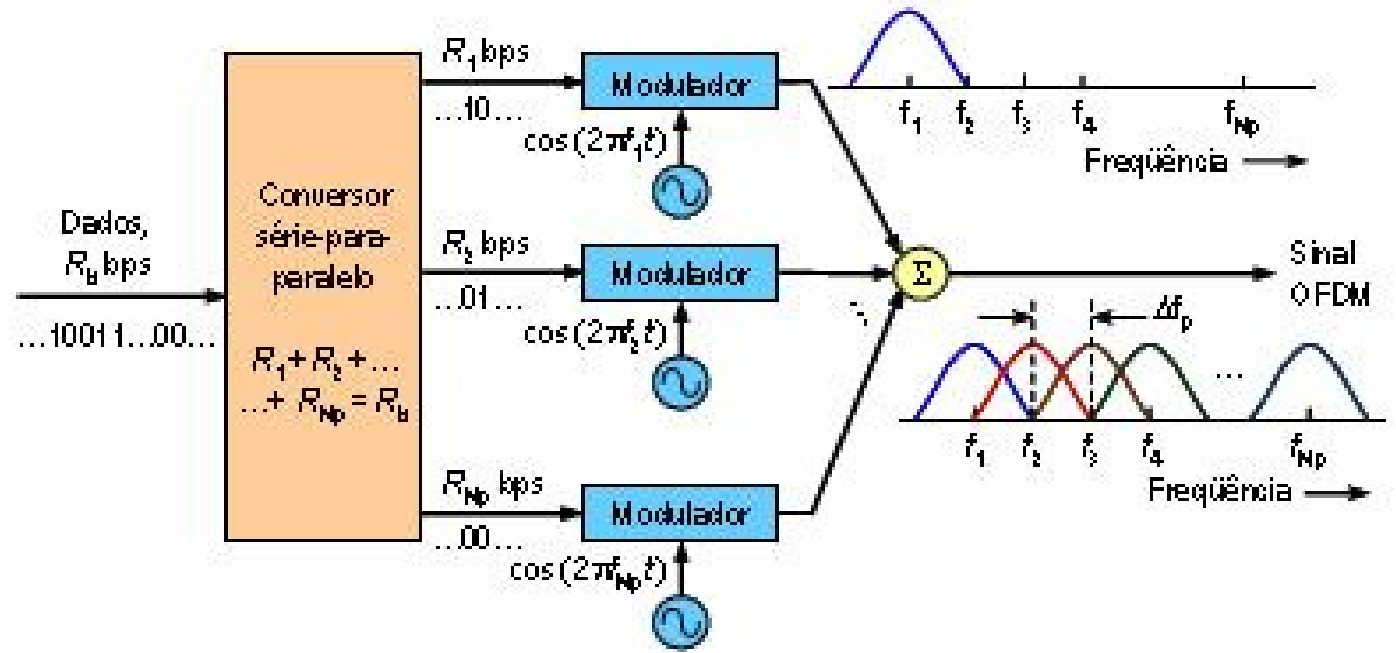

Figura 3.6 Ortogonalidade entre as portadoras na modulação COFDM [23]. 
A técnica COFDM se mostra bastante resistente às interferências intersimbólicas causadas pelo multi-percurso. O sinal que é enviado pela emissora percorre múltiplos caminhos até chegar ao receptor, que recebe diversas versões do mesmo defasadas no tempo. O sinal recebido é a soma de todas as versões do sinal enviado. O receptor para decodificar o sinal irá analisar cada um dos símbolos e se o atraso entre as versões recebidas do sinal digitalizado for maior que a duração de cada símbolo ocorrerá a interferência intersimbólica.

Como mencionado anteriormente, os esquemas de modulação de múltiplas portadoras permitem que a duração de cada símbolo seja bastante superior aos sistemas de portadora única. Isso torna a técnica COFDM bastante robusta às interferências multipercurso.

Para aumentar ainda mais a robustez do sistema COFDM, um intervalo de guarda é inserido entre cada um dos símbolos, fazendo com que a duração dos mesmos seja maior e reduzindo ainda mais as chances de ocorrer a interferência intersimbólica.

O COFDM é um sistema versátil, pois um grande número de parâmetros pode ser ajustado de acordo com as necessidades do transmissor, como por exemplo, o número de portadoras, a duração do intervalo de guarda e de cada símbolo, taxas de código de correção de erros, espaçamento e tipos de modulação por portadora, dependendo do sistema a ser projetado. A escolha destes parâmetros é influenciada diretamente pelos requisitos do sistema, como por exemplo, largura de banda e taxa de bits desejada. A Figura 3.7 mostra um esquema simplificado do sistema COFDM.

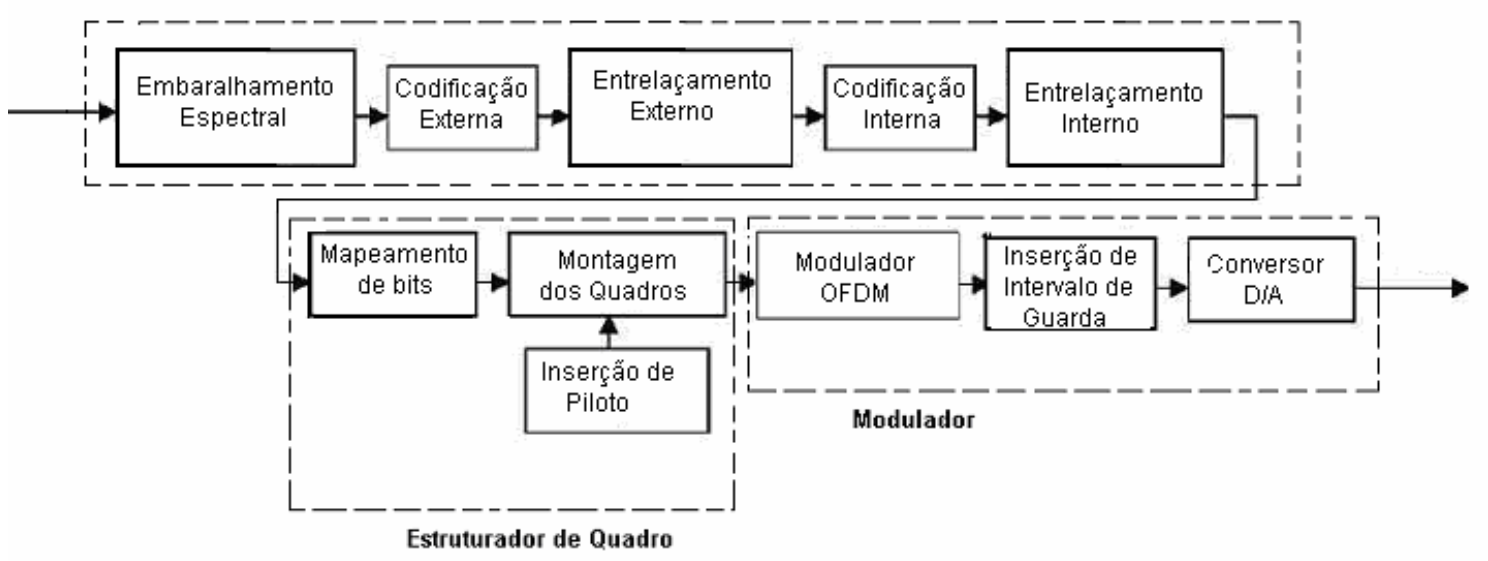

Figura 3.7 Processo de codificação e modulação OFDM.

O estágio de codificação do sistema COFDM é bastante semelhante ao da técnica 8VSB. O primeiro estágio do codificador é o embaralhador de dados, que 
tem como objetivo distribuir a energia do sinal digitalizado de maneira uniforme. $O$ segundo estágio, o de codificação externa, utiliza o codificador Reed Solomon para introduzir bits de redundância e possibilitar a correção de erros no receptor. Os símbolos são então entrelaçados para que o sinal se torne robusto às interferências do tipo burst. O estágio de codificação interna é um outro FEC que funciona de forma complementar ao codificador Reed Solomon. É do tipo convolucional, como o codificador de Treliça utilizado no esquema 8VSB, mas com a diferença de que no sistema 8VSB a razão do código (2/3) não pode ser alterada, enquanto que no sistema COFDM essa razão pode ser escolhida de acordo com o nível de robustez desejado. Assim, pode-se configurar o Codificador Interno para trabalhar com taxas de codificação de 1/2, 2/3, 3/4, 5/6 e 7/8. A taxa de bits na saída do codificador depende da taxas de codificação escolhida, quanto menor a fração, maior será a taxa de bits em relação à entrada [12].

Após o entrelaçamento interno os bits são mapeados para compor os símbolos e quadros da transmissão. São definidos o tipo de modulação (QPSK, 16QAM ou 64-QAM), o número de portadoras e a duração do intervalo de guarda. Para uma dada configuração dos parâmetros supracitados, os bits são agrupados para formar uma palavra. Cada palavra irá modular uma portadora, e o conjunto de palavras de todas as portadoras num dado intervalo de tempo é chamado de símbolo COFDM. Cada conjunto de 68 símbolos COFDM forma um quadro.

Algumas das portadoras são utilizadas como sinal piloto para obter sincronismo e controle de fase. Nas demais portadoras algumas palavras são utilizadas para atuar como sinais pilotos dispersos, que são usados para estimar as características de transmissão da portadora e de portadoras adjacentes.

\subsubsection{Técnicas de Modulação de Portadora Única Versus Sistemas de Múltiplas Portadoras}

As técnicas de modulação de portadora única (SCM) são muito mais sensíveis às interferências causadas por ruído impulsivo e pelo multipercurso já que cada símbolo tem curta duração. Para se eliminar os erros causados pelas interferências são utilizados complexos equalizadores nos receptores dos sistemas SCM, e mesmo assim estes não têm a mesma performance que os sistemas de múltiplas portadoras apresentam nas mesmas circunstâncias.

Já os sistemas de múltiplas portadoras têm a possibilidade de aumentar a duração de transmissão de cada símbolo, fazendo com que o sistema seja mais 
robusto às interferências [24]. A desvantagem da técnica MCM é o elevado grau de complexidade dos processos de modulação e demodulação, que cresce de acordo com o aumento do número de portadoras. 


\section{O SISTEMA ISDB}

\subsection{INTRODUÇÃO}

Integrated Services Digital Broadcasting (ISDB) é o sistema de transmissão digital japonês desenvolvido pelo Dibeg (Digital Broadcasting Experts Group) - que promove e especifica o sistema de difusão terrestre de televisão digital japonês - e mantido pela ARIB (Association of Radio Industries and Business), que é o órgão japonês responsável por desenvolver pesquisas na área de telecomunicações e por divulgar as novas tecnologias desenvolvidas naquele país.

O ISDB é um sistema integrado constituído de três tipos de serviços: transmissão via satélite (ISDB-S), transmissão via cabo (ISDB-C) e transmissão terrestre (ISDB-T). O serviço de transmissão terrestre do ISDB além de possuir uma versão para transmissão de televisão digital também apresenta uma versão para transmissão digital de áudio, o Integrated Services Digital Broadcasting - Terrestrial Sound Broadcasting, ISDB-T sb.

Todos os três serviços já se encontram em operação no Japão e têm encontrado ótima aceitação da população do País. O ISDB-T entrou em operação em dezembro de 2003 e após um ano, 18 milhões de lares, 38\% do total do País, já possuíam receptor de TV digital. A expectativa é que até o final do ano de 2006 o sistema esteja em operação em todas as partes do País e que em 2011 todos os lares já estejam prontos para receber a TV Digital. Estima-se que nesse ano a transmissão de TV analógica via satélite, cabo e terrestre seja interrompida, dando lugar à transmissão de TV digital. 


\subsection{ISDB-S e ISDB-C}

O sistema ISDB-S entrou em operação no Japão em dezembro de 2001. Este padrão foi desenvolvido pela ARIB para substituir o sistema de transmissão via satélite que já era utilizado no Japão desde 1996, o Digital Video BroadcastingSatellite, DVB-S. Enquanto o DVB-S tem como capacidade máxima de transmissão 34 Mbps, que permite a transmissão de apenas um canal HDTV por transponder, o ISDB-S tem capacidade de transmissão de até $51 \mathrm{Mbps}$, o que o possibilita transmitir até dois canais HDTV por transponder. A largura de banda ocupada é de $34,5 \mathrm{MHz}$, enquanto que no sistema analógico era de $27 \mathrm{MHz}$ [25].

Uma das características do sistema ISDB-S é mostrar-se flexível por permitir a transmissão hierárquica. O sistema permite que se opte entre três esquemas de modulação: TC8PSK (Trellis-Coded 8 Phase-Shift Keying), QPSK (Quadrature Phase-Shift Keying) e BPSK (Binary Phase-Shift Keying). É possível então que o transmissor escolha a modulação BPSK para modular informação de áudio, por apresentar maior robustez à atenuação durante a transmissão, enquanto que as informações de vídeo podem ser moduladas utilizando-se a técnica TC8PSK, que oferece a maior taxa de transmissão [25].

A primeira transmissão de TV digital a cabo ocorreu em 1996, empregando a modulação 64-QAM (Quadrature Amplitude Modulation). O sistema ISDB-C utiliza uma largura de banda de $6 \mathrm{MHz}$ e tem capacidade de transmitir $29 \mathrm{Mbps}$, metade da capacidade de transmissão via satélite [26].

Um resumo das principais características de cada um dos serviços integrantes do sistema ISDB pode ser visualizado na Tabela 4.1.

Tabela 4.1 Características dos serviços que integram o sistema ISDB.

\begin{tabular}{|c|c|c|c|c|}
\hline & & & & \\
\hline \multicolumn{2}{|c|}{ Sistema } & ISDB-S & ISDB-C & ISDB-T \\
\hline \multicolumn{2}{|c|}{ Codificação de áudio } & \multicolumn{3}{|c|}{ MPEG- 2 Video } \\
\hline \multicolumn{2}{|c|}{ Codificação de Vídeo } & \multicolumn{3}{|c|}{ MPEG-2 AAC } \\
\hline \multicolumn{2}{|c|}{ Multiplexação } & \multicolumn{3}{|c|}{ MPEG-2 } \\
\hline \multirow{2}{*}{$\begin{array}{c}\text { Correção } \\
\text { de Erro }\end{array}$} & Interna & Trellis Code & - & Conv. Code $(1 / 2,7 / 8)$ \\
\hline & Externa & \multicolumn{3}{|c|}{ Reed-Solomon Code $(204,188)$} \\
\hline \multicolumn{2}{|c|}{ Modulação } & $\begin{array}{c}\text { TC-8PSK, QPSK, } \\
\text { BPSK }\end{array}$ & 64-QAM & OFDM Segmentado - \\
\hline \multicolumn{2}{|c|}{ Taxa de Bits } & $52,17 \mathrm{Mbps}$ & 28,6 Mbps & 3,7-23,3 Mbps \\
\hline \multicolumn{2}{|c|}{$\begin{array}{c}\text { Largura de Banda do } \\
\text { Canal }\end{array}$} & $35,5 \mathrm{MHz}$ & $6 \mathrm{MHz}$ & $6 \mathrm{MHz}$ (UHF-VHF) \\
\hline
\end{tabular}




\subsection{ISDB-Tsb}

O sistema japonês de rádio digital é conhecido como ISDB-T SB $_{\text {(Integrated }}$ Services Digital Broadcasting - Terrestrial Segmented Band). Assim como os outros padrões de rádio digital, o ISDB-TSB também utiliza a técnica de modulação OFDM. No entanto, nesse sistema, as sub-portadoras são agrupadas em grupos chamados segmentos. Para transmissão de TV Digital são utilizados 13 segmentos, cada um com largura de $430 \mathrm{kHz}$. No caso do rádio digital são usados apenas um ou três segmentos, correspondendo a uma taxa de transmissão de 200 a $300 \mathrm{kbits} / \mathrm{s}$ no caso de um segmento e até 1 Mbps para três segmentos [10].

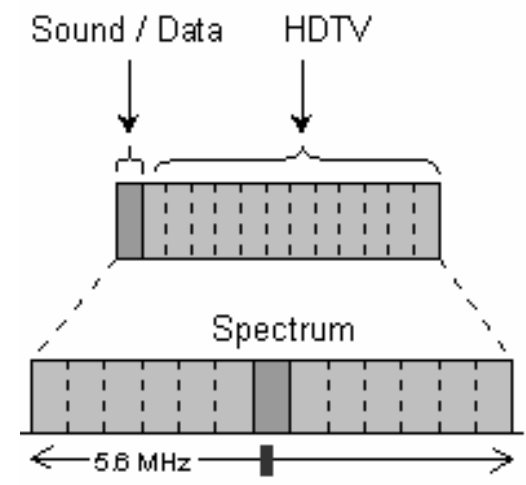

SDB-T radiodifusẫo de $T V$ e dados

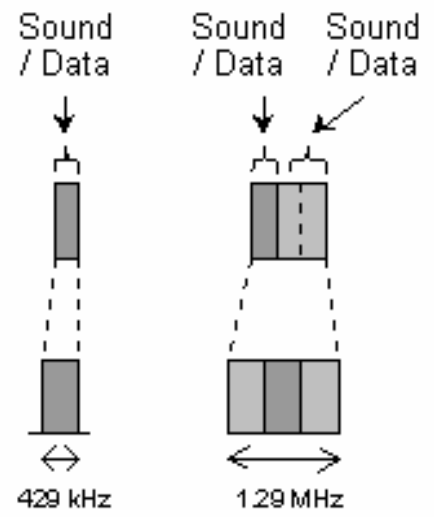

ISDB-T banda estreita radiodifusẫo de áudio e dados

Figura 4.1 Sinal ISDB-T de Banda Integral e ISDB-T de Banda Estreita [9].

Como o ISDB-T $T_{S B}$, também conhecido como ISDB-T de banda estreita, é uma "fração" do ISDB-T, o sistema foi projetado de forma que os dois modos de transmissão sejam compatíveis, ou seja, o receptor de TV é capaz de receber o sinal de áudio e dados transmitido em banda estreita, e de forma análoga, o receptor de rádio é capaz de decodificar a parte de áudio do sinal de televisão [4], [10].

Outra característica importante do ISDB- $T_{\mathrm{sb}}$ é a capacidade de realizar transmissão hierárquica, ou seja, a parte mais importante da informação é colocada em segmentos que receberão uma técnica de modulação mais robusta, enquanto que informação secundária é alocada em segmentos com menor proteção. $O$ sistema ISDB-T de 13 segmentos apresenta até 3 camadas de hierarquização enquanto que o ISDB-T $\mathrm{TB}_{\mathrm{SB}}$ possui apenas duas [4], [10]. O sistema ISDB-T $\mathrm{SB}_{\mathrm{S}}$ disponibiliza quatro esquemas de modulação de portadoras: DQPSK, QPSK, 16QAM e 64-QAM. 
Um inconveniente do sistema ISDB-T $\mathrm{SB}_{\mathrm{SB}}$ é o fato dele não ser um sistema inband, ou seja, não é compatível com a atual estrutura de canalização adotada para a radiodifusão $\mathrm{FM}$ em VHF, sendo necessário, por esta razão, alocar uma faixa de freqüência exclusiva para ele [1].

A tabela a seguir apresenta alguns parâmetros do sistema ISDB-T sb. $_{\text {. }}$

Tabela 4.2 - Parâmetros do sistema ISDB-T ${ }_{\mathrm{sb}}$ [28].

\begin{tabular}{|c|c|c|c|}
\hline Modo & Modo 1 & Modo 2 & Modo 3 \\
\hline Número de Segmentos & \multicolumn{3}{|c|}{1 ou 3} \\
\hline Largura de Banda & \multicolumn{3}{|c|}{$428 \mathrm{kHz}$ ou $1,3 \mathrm{MHz}$} \\
\hline $\begin{array}{l}\text { Espaçamento das } \\
\text { Portadoras }\end{array}$ & $250 / 63=3,96 \mathrm{kHz}$ & $125 / 63=1,98 \mathrm{kHz}$ & $125 / 126=0,99 \mathrm{kHz}$ \\
\hline Número de Portadoras & $109 / 325$ & $217 / 649$ & $433 / 1297$ \\
\hline $\begin{array}{l}\text { Esquemas de } \\
\text { Modulação }\end{array}$ & \multicolumn{3}{|c|}{ QPSK, DQPSK, 64QAM, 16QAM } \\
\hline $\begin{array}{c}\text { Duração Efetiva dos } \\
\text { Símbolos } \\
\end{array}$ & $252 \mu \mathrm{s}$ & $504 \mu \mathrm{s}$ & $1008 \mu \mathrm{s}$ \\
\hline $\begin{array}{l}\text { Duração do Intervalo } \\
\text { de Guarda }\end{array}$ & $\begin{array}{c}63 \mu \mathrm{s}(1 / 4) \\
31,5 \mu \mathrm{s}(1 / 8) \\
15,75 \mu \mathrm{s}(1 / 16) \\
7,875 \mu \mathrm{s}(1 / 32)\end{array}$ & $\begin{array}{c}126 \mu \mathrm{s}(1 / 4) \\
63 \mu \mathrm{s}(1 / 8) \\
31,5 \mu \mathrm{s}(1 / 16) \\
15,75 \mu \mathrm{s}(1 / 32) \\
\end{array}$ & $\begin{array}{c}252(1 / 4) \\
126 \mu \mathrm{s}(1 / 8) \\
63 \mu \mathrm{s}(1 / 16) \\
31,5 \mu \mathrm{s}(1 / 32)\end{array}$ \\
\hline Codificação Interna & \multicolumn{3}{|c|}{ Código Convolucional (1/2, 2/3, 3/4, 5/6, 7/8) } \\
\hline Codificação Externa & \multicolumn{3}{|c|}{ Reed Solomon $(204,188)$} \\
\hline
\end{tabular}

\subsection{ISDB-T}

O padrão de transmissão de televisão digital terrestre ISDB-T foi concebido para possibilitar a transmissão de televisão digital de alta definição e a recepção do sinal de televisão digital em receptores móveis e sem fio. O ISDB-T é uma evolução do sistema europeu DVB e apresenta como principal diferencial a estrutura de banda segmentada. A banda de transmissão do ISDB-T é dividida em 13 segmentos independentes, que podem ser divididos em até três camadas distintas. Essas 
camadas podem ter seus parâmetros de transmissão ajustados de forma independente, possibilitando assim a transmissão hierárquica.

\subsubsection{Segmentação de banda}

O sistema ISDB-T apresenta versões para canalização de $6 \mathrm{MHZ}, 7 \mathrm{MHz}$ e $8 \mathrm{MHz}$, o que possibilita a sua adoção em todo o mundo - no entanto, até o presente momento, só foi adotado pelo Japão e Brasil. Para a canalização de $6 \mathrm{MHz}$, adotada no Brasil, cada um dos 13 segmentos apresenta uma largura de $428,57 \mathrm{kHz}$, totalizando $5,571 \mathrm{MHz}$, com $4 \mathrm{kHz}$ de banda de guarda.

O esquema de segmentação do canal em 13 segmentos é representa do na figura 4.2 .

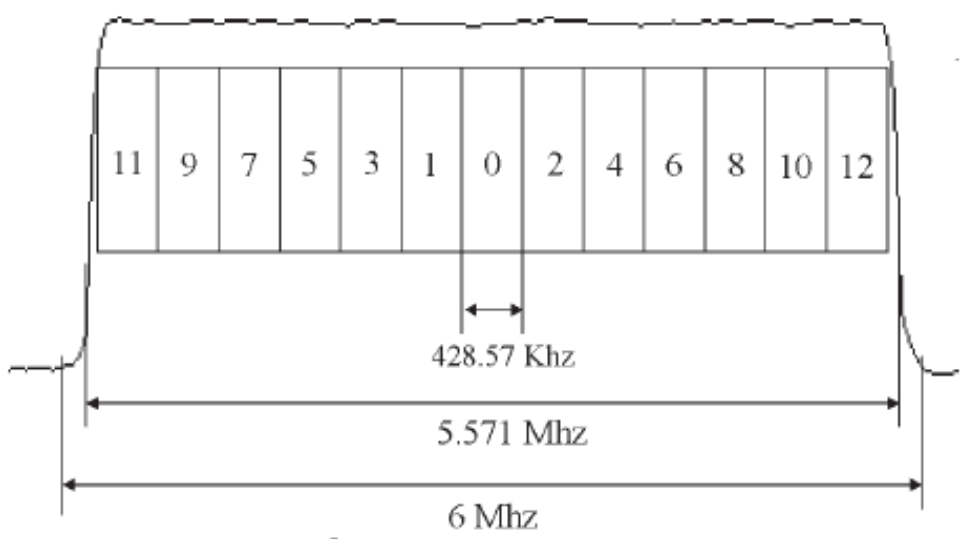

Figura 4.2 Esquema de segmentação da banda [12].

A divisão da banda em 13 segmentos distintos é uma inovação do ISDB-T em relação ao DVB-T. Essa característica viabiliza o objetivo para o qual o sistema foi concebido: oferecer, em uma mesma plataforma tecnológica, diversos serviços de comunicação, permitindo a convergência total das transmissões televisivas com a Internet e telefones celulares.

Uma novidade introduzida por este padrão é a possibilidade de efetuar transmissões do sinal de televisão digital para aparelhos portáteis e móveis que são equipados apenas com um receptor de banda estreita. Neste caso a informação é transmitida dentro da própria banda de $6 \mathrm{MHz}$ do canal sem requerer a utilização de serviços de operadoras de celular. 


\subsubsection{Flexibilidade}

Uma característica bastante vantajosa do padrão ISDB-T é sua flexibilidade, pois apresenta diversas alternativas para seus parâmetros de transmissão. Os 13 segmentos de banda podem ser divididos em até três camadas, sendo possível atribuir diferentes valores para os parâmetros de transmissão de cada uma delas. Os parâmetros podem ser definidos de acordo com a necessidade de cada emissor, entre esses está o número de portadoras que serão utilizadas, o tipo de modulação que será adotado, a duração do intervalo de guarda e taxas de codificação. As tabelas seguir resumem os parâmetros do sistema ISDB-T.

Tabela 4.3 Parâmetros do ISDB-T [27].

\begin{tabular}{|c|c|c|c|}
\hline Modo & Modo 1 & Modo 2 & Modo 3 \\
\hline Número de Segmentos & \multicolumn{3}{|c|}{13} \\
\hline Largura de Banda & $\begin{array}{c}5,571+(250 / 63) \\
5,575 \mathrm{MHz}\end{array}=$ & $\begin{array}{r}5,571+(125 / 63) \\
5,573 \mathrm{MHz}\end{array}$ & $\begin{array}{c}5,571+(125 / 126) \\
=5,572 \mathrm{MHz}\end{array}$ \\
\hline $\begin{array}{l}\text { Espaçamento das } \\
\text { Portadoras }\end{array}$ & $250 / 63=3,96 \mathrm{kHz}$ & $125 / 63=1,98 \mathrm{kHz}$ & $125 / 126=0,99 \mathrm{kHz}$ \\
\hline Número de Portadoras & 1405 & 2809 & 4992 \\
\hline $\begin{array}{l}\text { Esquemas de } \\
\text { Modulação }\end{array}$ & \multicolumn{3}{|c|}{ QPSK, DQPSK, 16QAM, 64QAM } \\
\hline $\begin{array}{l}\text { Número de Símbolos } \\
\text { por Quadro }\end{array}$ & \multicolumn{3}{|c|}{204} \\
\hline $\begin{array}{c}\text { Duração Efetiva dos } \\
\text { Símbolos }\end{array}$ & $252 \mu s$ & $504 \mu \mathrm{s}$ & $1008 \mu \mathrm{s}$ \\
\hline $\begin{array}{l}\text { Duração do Intervalo } \\
\text { de Guarda }\end{array}$ & $\begin{array}{c}63 \mu \mathrm{s}(1 / 4) \\
31,5 \mu \mathrm{s}(1 / 8) \\
15,75 \mu \mathrm{s}(1 / 16) \\
7,875 \mu \mathrm{s}(1 / 32) \\
\end{array}$ & $\begin{array}{c}126 \mu \mathrm{s}(1 / 4) \\
63 \mu \mathrm{s}(1 / 8) \\
31,5 \mu \mathrm{s}(1 / 16) \\
15,75 \mu \mathrm{s}(1 / 32) \\
\end{array}$ & $\begin{array}{c}252(1 / 4) \\
126 \mu \mathrm{s}(1 / 8) \\
63 \mu \mathrm{s}(1 / 16) \\
31,5 \mu \mathrm{s}(1 / 32) \\
\end{array}$ \\
\hline Codificação Interna & \multicolumn{3}{|c|}{ Código Convolucional (1/2, 2/3, 3/4, 5/6, 7/8) } \\
\hline Codificação Externa & \multicolumn{3}{|c|}{ Reed Solomon $(204,188)$} \\
\hline
\end{tabular}


Tabela 4.4 Parâmetros do ISDB-T [27].

\begin{tabular}{|c|c|c|c|c|c|}
\hline \multirow{2}{*}{$\begin{array}{l}\text { Esquema de } \\
\text { Modulação }\end{array}$} & \multirow{2}{*}{$\begin{array}{c}\text { Taxa do Código } \\
\text { Convolucional }\end{array}$} & \multicolumn{4}{|c|}{ Capacidade de Transmissão (Mbps) } \\
\hline & & $\begin{array}{c}\text { Intervalo de } \\
\text { Guarda } \\
1 / 4\end{array}$ & $\begin{array}{c}\text { Intervalo de } \\
\text { Guarda } \\
1 / 8\end{array}$ & $\begin{array}{c}\text { Intervalo de } \\
\text { Guarda } \\
1 / 16\end{array}$ & $\begin{array}{c}\text { Intervalo de } \\
\text { Guarda } \\
1 / 32\end{array}$ \\
\hline \multirow{5}{*}{$\begin{array}{c}\text { QPSK } \\
\text { DQPSK }\end{array}$} & $1 / 2$ & 3,651 & 4,056 & 4,295 & 4,425 \\
\hline & $2 / 3$ & 4,868 & 5,409 & 5,727 & 5,900 \\
\hline & $3 / 4$ & 5,476 & 6,085 & 6,433 & 6,638 \\
\hline & $5 / 6$ & 6,085 & 6,761 & 7,159 & 7,376 \\
\hline & $7 / 8$ & 6,389 & 7,099 & 7,517 & 7,744 \\
\hline \multirow{5}{*}{ 16QAM } & $1 / 2$ & 7,302 & 8,113 & 8,590 & 8,851 \\
\hline & $2 / 3$ & 9,736 & 10,818 & 11,454 & 11,801 \\
\hline & $3 / 4$ & 10,953 & 12,170 & 12,886 & 13,276 \\
\hline & $5 / 6$ & 12,170 & 13,522 & 14,318 & 14,752 \\
\hline & $7 / 8$ & 12,779 & 14,198 & 15,034 & 15,489 \\
\hline \multirow{5}{*}{ 64QAM } & $1 / 2$ & 10,953 & 12,170 & 12,886 & 13,276 \\
\hline & $2 / 3$ & 14,604 & 16,227 & 17,181 & 17,702 \\
\hline & $3 / 4$ & 16,430 & 18,255 & 19,329 & 19,915 \\
\hline & $5 / 6$ & 18,255 & 20,284 & 21,477 & 22,128 \\
\hline & $7 / 8$ & 19,168 & 21,298 & 22,551 & 23,234 \\
\hline
\end{tabular}

\subsubsection{Duração útil do símbolo}

A duração útil de um símbolo é definida como o tamanho efetivo da informação, desconsideram-se, então, os intervalos de guarda entre cada um dos símbolos. Para uma mesma taxa de transmissão de dados, quanto maior o número de portadoras OFDM tem-se uma maior duração de cada símbolo e conseqüentemente o sinal apresentará maior robustez frente às interferências. $A$ duração de um símbolo é inversamente proporcional ao espaçamento das subportadoras e existe um limite máximo de duração do símbolo para que as mesmas não fiquem muito próximas. Quanto menor o intervalo entre as portadoras, mais susceptível o sinal será ao Efeito Doppler. Cuidado especial deverá ser tomado em transmissões para receptores móveis, já que nesses casos o Efeito Doppler é mais significativo. A escolha da duração do intervalo de guarda é uma relação de compromisso entre um sistema robusto ao multipercurso e um sistema que não sofre com o Efeito Doppler, fica a cargo do emissor decidir qual configuração é o mais apropriado para o ambiente onde ocorrerá a transmissão. 


\subsubsection{Número de sub-portadoras}

O sistema ISDB-T oferece três modos de operação que se diferenciam pelo número de portadoras OFDM empregadas durante a transmissão, a saber:

- Modo 1: 1405 portadoras

- Modo 2: 2809 portadoras

- Modo 3: 4992 portadoras

A escolha do modo de operação depende, sobretudo, do nível de urbanização e da geografia da região onde serão realizadas as transmissões de televisão digital. Grandes cidades que apresentam um elevado número de edificações e áreas geograficamente acidentadas, caracterizadas pela presença de muitas montanhas apresentam grandes problemas de propagação multi-percurso.

Como já mencionado anteriormente, a técnica OFDM atenua os problemas de interferência causados pelo multi-percurso, pois utiliza múltiplas portadoras fazendo com que a duração de cada símbolo seja maior. Quanto maior o número de portadoras, maior será a imunidade do sinal frente à interferências multi-percurso.

Para o tipo de região mencionado, o modo 3 de operação, que apresenta maior número de portadoras, seria o mais ideal. Pode parecer atrativo, então, aumentar muito o número de portadoras para que o sinal se torne cada vez mais robusto. No entanto, o número de portadoras não poderia ser aumentado indefinidamente, visto que quanto mais portadoras, menor o espaçamento entre elas, surgindo, então, alguns problemas, como grande complexidade na implementação dos transmissores e receptores, problemas de sincronismo e o maior deles que é o efeito Doppler, em que qualquer alteração nas freqüências será bastante perceptível, já que as portadoras se encontram muito próximas.

Para áreas menos acidentadas é preferível operar num modo que apresente menos portadoras visto que não ocorrem muitos problemas de multipercurso. $\mathrm{O}$ mesmo se aplica para o caso de transmissões para receptores móveis, em que o efeito Doppler apresenta maior atuação.

\subsubsection{Esquema de modulação}

O sistema ISDB-T apresenta a possibilidade de escolha da técnica de modulação que será empregada nas sub-portadoras OFDM, são elas: 16QAM, 64QAM, QPSK e DQPSK [27]. A escolha da técnica de modulação a ser utilizada é uma relação de compromisso entre taxa de transmissão e robustez. Como o ISDB-T apresenta a possibilidade de dividir os 13 segmentos em 3 camadas distintas, cada 
uma dessas poderá adotar uma diferente técnica de modulação possibilitando a transmissão hierárquica que será discutida mais adiante.

\subsubsection{Intervalo de Guarda}

A adição de um intervalo de guarda entre cada símbolo do sinal se faz necessária para evitar a interferência intersimbólica. Quanto maior o intervalo de guarda, mais imune o sinal será a esse tipo de interferência, que é conseqüência da propagação multipercurso. No entanto, quanto maior o intervalo de guarda, menor a taxa de transmissão do sinal, uma vez que informações redundantes estão sendo transmitidas no lugar de novos dados. Em esquemas de modulação que apresentam maior capacidade de transmissão, como o 16QAM e 64QAM, cuidado adicional deve ser tomado na escolha da duração do intervalo de guarda, uma vez que estas técnicas são mais susceptíveis às interferências intersimbólicas. O sistema ISDB-T disponibiliza quatro diferentes valores de intervalo de guarda para cada um dos modos de operação, sendo que os valores podem ser escolhidos separadamente para cada um dos 13 segmentos.

\subsubsection{Taxa de Codificação de Erros}

A taxa de codificação determina quantos bits de redundância serão incorporados ao sinal original para torná-lo mais robusto às diversas fontes de interferências. A escolha da taxa de codificação é também uma relação de compromisso entre capacidade de transmissão e robustez. No sistema ISDB-T existem duas etapas de codificação de erros, uma interna e uma externa, sendo que somente a interna é flexível, ou seja, apresenta diversas taxas que podem ser escolhidas de acordo com o desejo do transmissor do sinal. A Figura 4.3 mostra a taxa de erro de bits (BER) para diversas taxas de codificação para o caso da modulação 64QAM, Modo 1 de operação e intervalo de guarda de 31,5 $\mu$ s. 


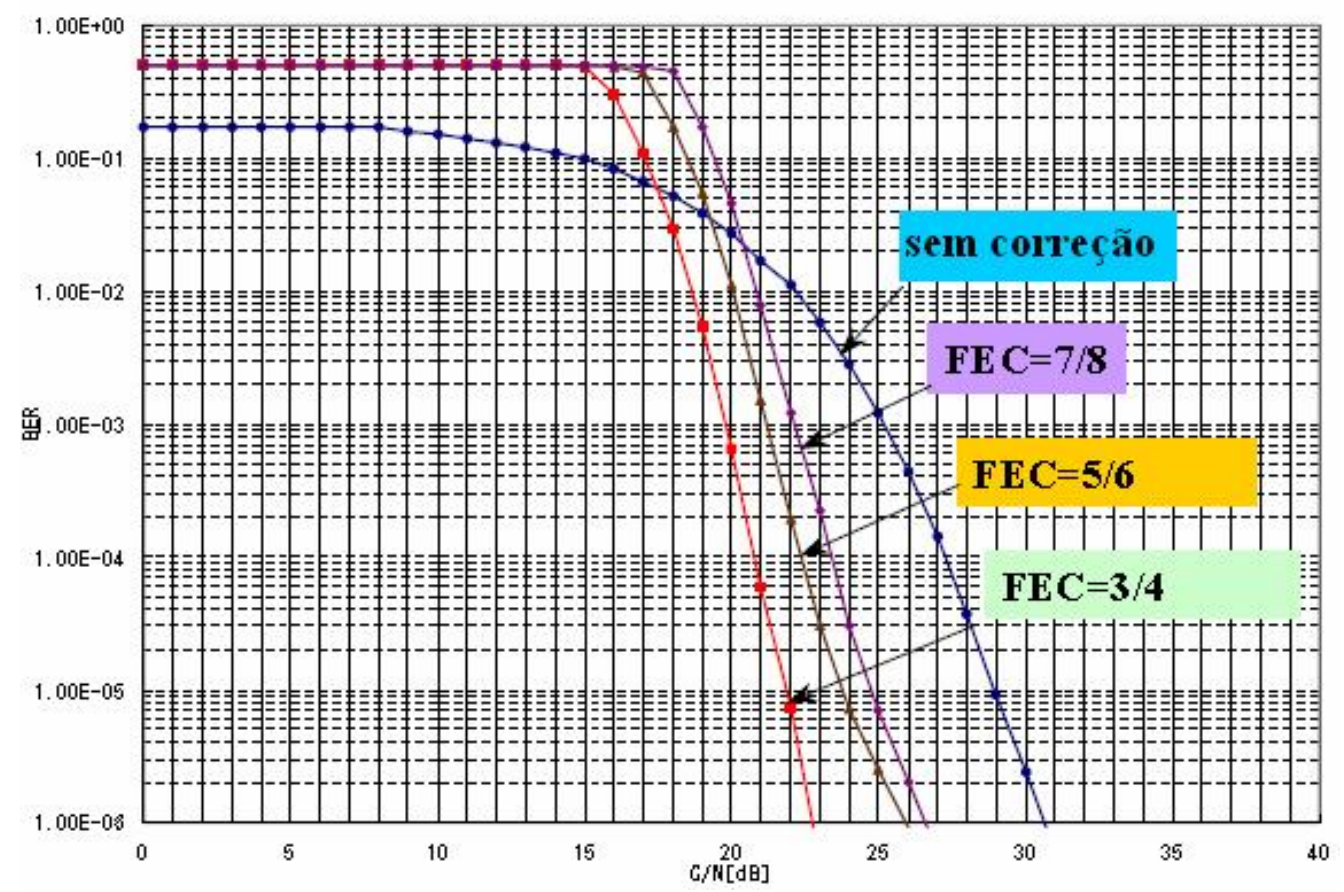

Figura 4.3 Taxa de BER para diferentes taxas de codificação para modulação 64QAM [28].

\subsubsection{Mobilidade e Portabilidade}

Com a busca incessante por avanços tecnológicos, uma quantidade crescente de produtos com novas funções aplicáveis à mídia digital, como terminais portáteis, Internet e telefones celulares, estão sendo introduzidos no mercado e despertando o interesse dos usuários.

Um aspecto fundamental da radiodifusão em termos de exploração do vasto potencial dessas tecnologias é o grau de flexibilidade com que a televisão digital terrestre poderá se adaptar à mídia digital e as necessidades que precisam ser atendidas.

A mobilidade e a portabilidade é possível no ISDB-T em razão desse sistema apresentar importantes características quanto a flexibilidade, como a transmissão hierárquica, em que os parâmetros são transmitidos com diferentes níveis de robustez; o fato de o sistema oferecer uma largura de faixa de recepção mínima de $430 \mathrm{kHz}$, contribuindo dessa forma com um menor consumo de energia pelo receptor portátil, já que o consumo de energia é proporcional a largura da faixa de recepção; além disso, o ISDB-T possui o modo de operação $4 \mathrm{k}$, que suporta as características de transmissão requeridas tanto para recepção fixa quanto para recepção móvel [19]. 
Um exemplo da aplicação da transmissão hierárquica para a viabilidade da recepção móvel ocorre quando se escolhe para a transmissão o esquema de modulação 64QAM e a correção de erro de 7/8 em todo o canal. Com esses parâmetros é possível alcançar uma capacidade de transmissão de cerca de 20 Mbps no canal de $6 \mathrm{MHz}$. Entretanto, para prover serviços para os receptores móveis e portáteis, a utilização dos esquemas de modulação DQPSK e 16QAM possibilita um desempenho melhor. Dessa forma, essas modulações são empregadas em parte do canal. A Figura 4.4 ilustra esse exemplo [21].

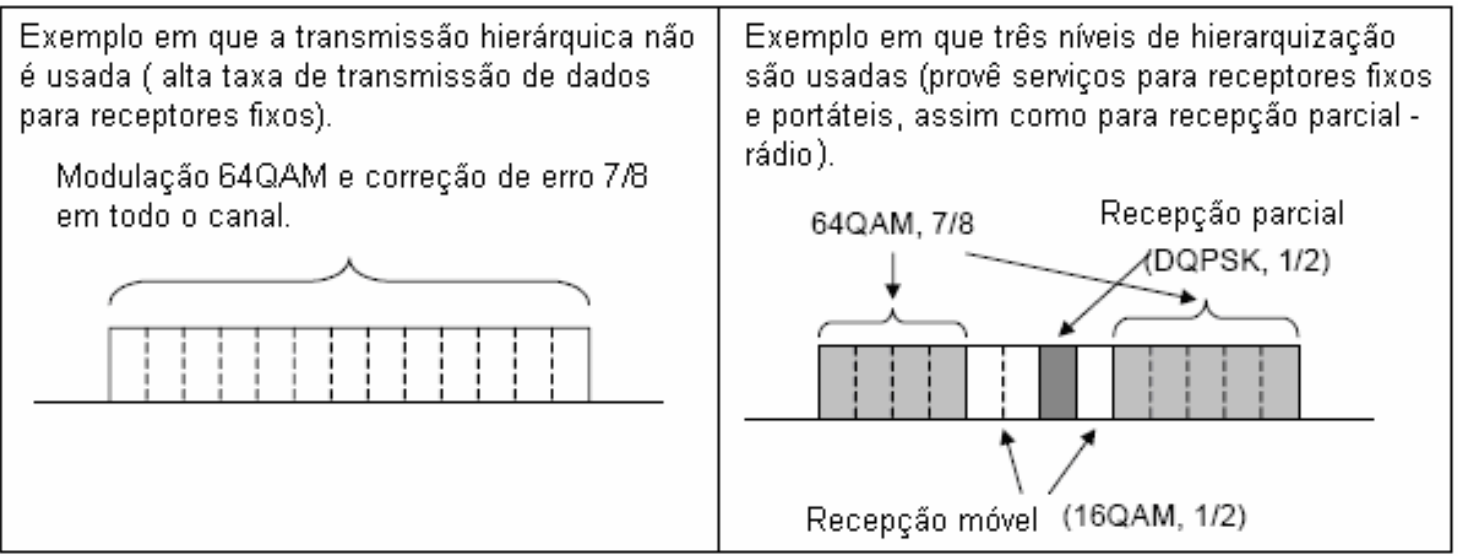

Figura 4.4 - A transmissão hierárquica aplicada na recepção móvel [21].

Com o intuito de aumentar a confiabilidade na transmissão de dados, a maioria dos esquemas de correção de erro são eficientes quando os erros são aleatórios. Entretanto, na recepção móvel há canais com características de erros do tipo rajada (ruído impulsivo). Um método eficiente de lidar com canais com erros do tipo rajada é fazer o embaralhamento do feixe de dados codificados de maneira a transformar um canal com erros de rajada tipo em um canal que tenha erros aleatórios.

$\mathrm{Na}$ recepção móvel, a intensidade de campo do sinal recebido pode ser alterada com 0 deslocamento do receptor. Em baixas velocidades, 0 desvanecimento e a flutuação causam reduções de sinal de longa duração que resultam em erros burst sem possibilidade de correção. Essa situação é ilustrada na Figura 4.5. 


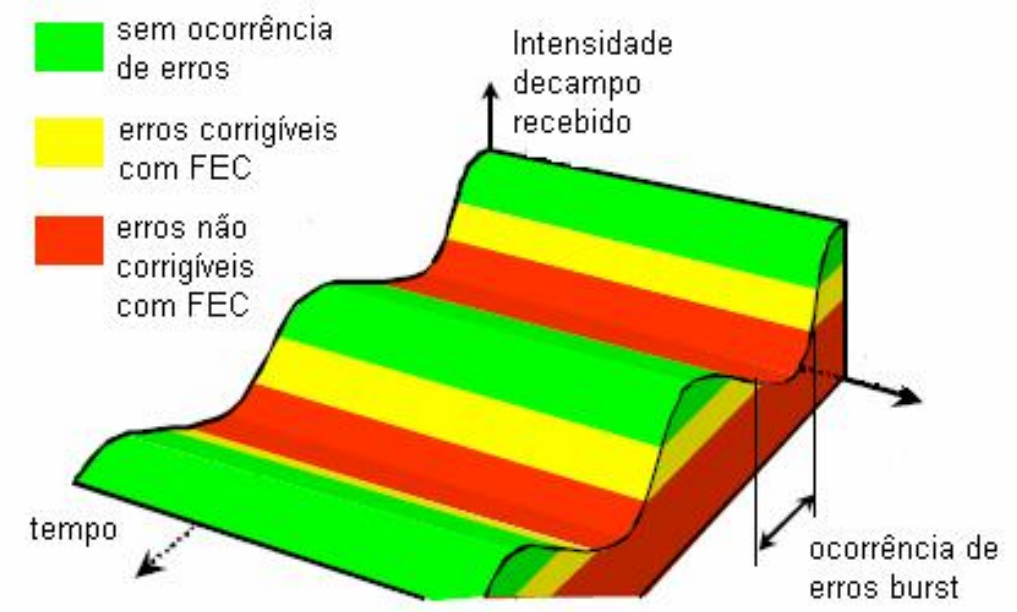

Figura 4.5 - Alteração na intensidade de campo com o deslocamento [20].

O mecanismo funciona da seguinte maneira: antes de ocorrer a transmissão, os elementos de dados adjacentes são afastados em até 0,5 segundos através da transposição temporal. Dessa forma, no receptor, o erro que antes era do tipo rajada é convertido para erro aleatório quando ocorre a operação inversa à transposição temporal, sendo, assim, possível de ser corrigido pelo sistema de correção de erros. A Figura 4.6 apresenta esse mecanismo [20].

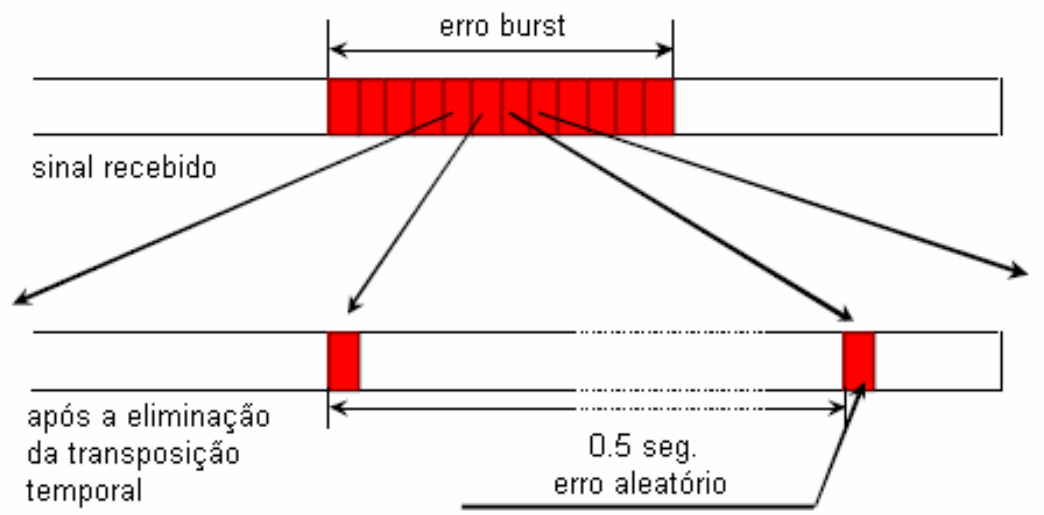

Figura 4.6 - Conversão do erro burst para erro aleatório [20].

Apesar de que a transposição temporal introduza um retardo de até 1 segundo, e isso não é bem visto pelos radiodifusores, esta desvantagem é desprezível em relação aos benefícios para a recepção móvel. 


\subsubsection{Transmissão Hierárquica}

A transmissão hierárquica possibilita que partes do sinal de televisão sejam transmitidas com diferentes graus de robustez. O sistema ISDB-T permite dividir o feixe inicial de informação em até três camadas, incluindo o segmento utilizado para recepção móvel, em que para cada uma delas pode ser escolhida uma taxa de codificação interna, a duração do intervalo de guarda e a técnica de modulação que será utilizada.

Pode-se ter, por exemplo, um canal de boa definição para a recepção fixa, mas não de grande robustez à interferência e outro canal de definição mais baixa destinado à recepção móvel, mas de robustez mais elevada. No caso de um canal de HDTV estar sendo transmitido, a informação básica para a recepção do sinal de televisão pode ser transmitida utilizando-se uma técnica de modulação mais robusta, às custas da capacidade de transmissão, enquanto que informações adicionais que enriqueceriam tanto som e imagem e forneceriam serviços adicionais poderiam utilizar técnicas de modulação que suportam maior taxa de bits mas com menor proteção.

O recurso da transmissão hierárquica possibilita a recepção móvel do sinal de televisão, que no caso do ISDB-T fica restrita a um único segmento aproximadamente $430 \mathrm{kHz}$. Para garantir a recepção do sinal em aparelhos móveis é necessário então empregar a técnica de modulação mais robusta, além de aplicar taxas de codificação e uma duração de intervalo de guarda adequada para que o sinal seja bastante resistente às interferências.

Caso esse recurso esteja sendo utilizado, o feixe de bits gerado pelo codificador de fonte é dividido em até três feixes distintos que serão codificados, modulados e posteriormente voltam a formar um único feixe de bits para que a técnica OFDM seja empregada e o sinal de televisão seja finalmente transmitido. Deve-se sempre transmitir a parte principal da informação com robustez superior às outras para que esta possa ser decodificada sozinha caso o restante da informação seja perdido.

Diferentemente, na transmissão não-hierárquica, todas as informações são transmitidas com o mesmo grau de proteção, proporcionando a todos os dados 0 mesmo nível de robustez. A plataforma ATSC não permite a transmissão hierárquica, ao contrário das plataformas DVB e ISDB que viabilizam este tipo de operação. 


\subsubsection{Codificação de Canal do Sistema ISDB-T}

O estágio de codificação de canal do sistema ISDB-T é dividido em duas etapas: o bloco de codificação externa e o bloco de codificação interna. A etapa de codificação externa é fixa e formada por um aleatorizador de dados e de um codificador de correção de erros Reed Solomon com entrelaçador de bytes. $O$ estágio de codificação de canal interna é flexível, sendo composto de um codificador convolucional de taxas 1/2, 2/3,3/4,5/6,7/8, que podem ser definidas de acordo com a conveniência do transmissor. Um diagrama de blocos do codificador de canal do sistema ISDB-T é ilustrado na Figura 4.4 [27].

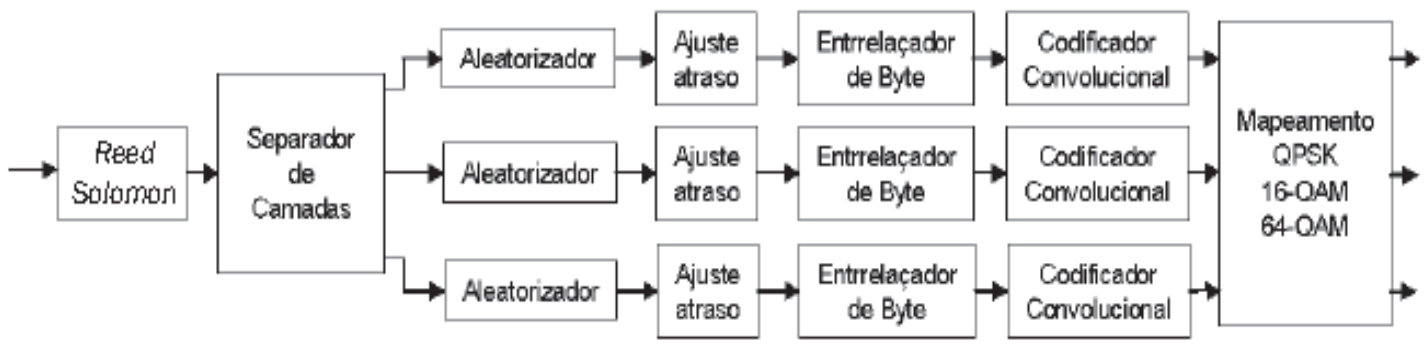

Figura 4.7 Diagrama de blocos do esquema de codificadoção de canal do sistema ISDB-T [12].

As seqüências de bits geradas pelo codificador de fonte são codificadas pelo código Reed Solomon, que no sistema ISDB apresenta como entrada pacotes de 188 bytes e acrescenta 16 bytes de paridade, totalizando 204 bytes na saída [12].

$\mathrm{Na}$ saída do codificador Reed Solomon os feixes de pacotes de 204 bytes podem ser separados em até três camadas distintas, A, B e C, e neste caso o recurso de transmissão hierárquica estará sendo utilizado. Se esse recurso não for necessário, então todos os pacotes são encaminhados para uma mesma camada.

Em seguida as seqüências de bytes seguem para um aleatorizador de dados, ou dispersor de energia, que torna a distribuição de bytes dentro de cada pacote aleatória. Esse procedimento se faz necessário para evitar a concentração de energia no espectro do sinal modulado, que ocorre devido à repetição de padrões de dados, e caso não fosse realizado o sinal seria mais susceptível a interferências.

A etapa seguinte é a compensação dos atrasos relativos nas três camadas de dados e posteriormente os bytes são embaralhados para que o sinal se torne mais imune a ruído do tipo impulsivo. 
Cada um dos feixes de bytes das três camadas passa, então, pela etapa de codificação interna, em que a escolha da taxa de codificação é uma relação de compromisso entre robustez e capacidade de transmissão de bits. A taxa de codificação interna pode ser escolhida separadamente para cada um dos 13 segmentos [27]. Os bits são então mapeados para serem introduzidos no estágio do modulador, em que cada uma dos milhares de sub-portadoras são moduladas individualmente para posteriormente ser gerado o sinal modulado OFDM [12].

\subsubsection{Modulador}

Um diagrama de blocos do modulador do sistema ISDB-T está representado na Figura 4.5.

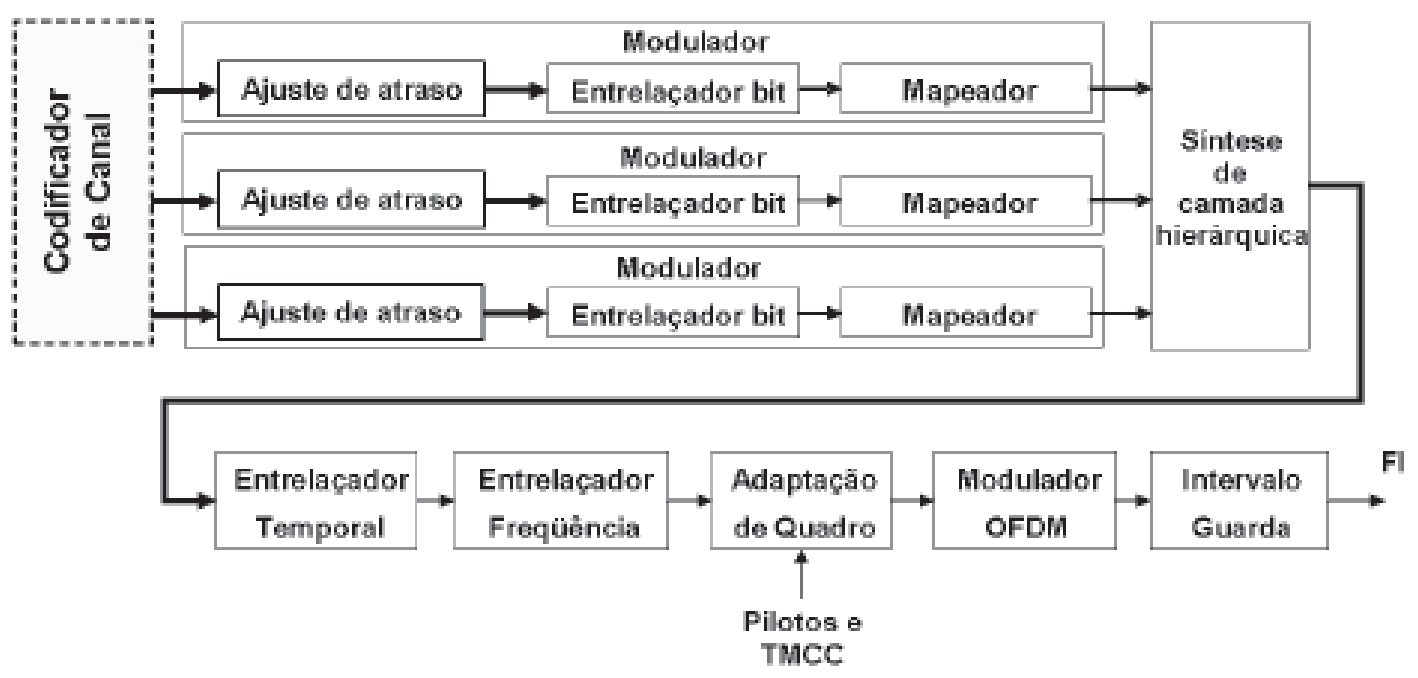

Figura 4.8 Diagrama de blocos do modulador [12].

O primeiro bloco do modulador do ISDB-T é constituído por uma modulação primária que pode ser escolhida entre as técnicas QPSK, DQPSK, 16QAM e 64QAM. Como pode ser verificado na Tabela 4.4, as técnicas QPSK e DQPSK apresentam menores taxas de transmissão, mas em compensação, são esquemas de modulação mais robustos às interferências. Em contrapartida, os esquemas de modulação 16QAM e 64QAM apresentam maiores taxas de transmissão, sendo o esquema 64QAM o de maior capacidade, porém são mais susceptíveis ao ruído durante a transmissão. A Figura 4.6 apresenta a taxa de erro de bits (BER) para as quatro técnicas de modulação disponíveis com o sistema operando no Modo 1, com intervalo de guarda de $31,5 \mu$ s e taxa de correção de erros $3 / 4$. 


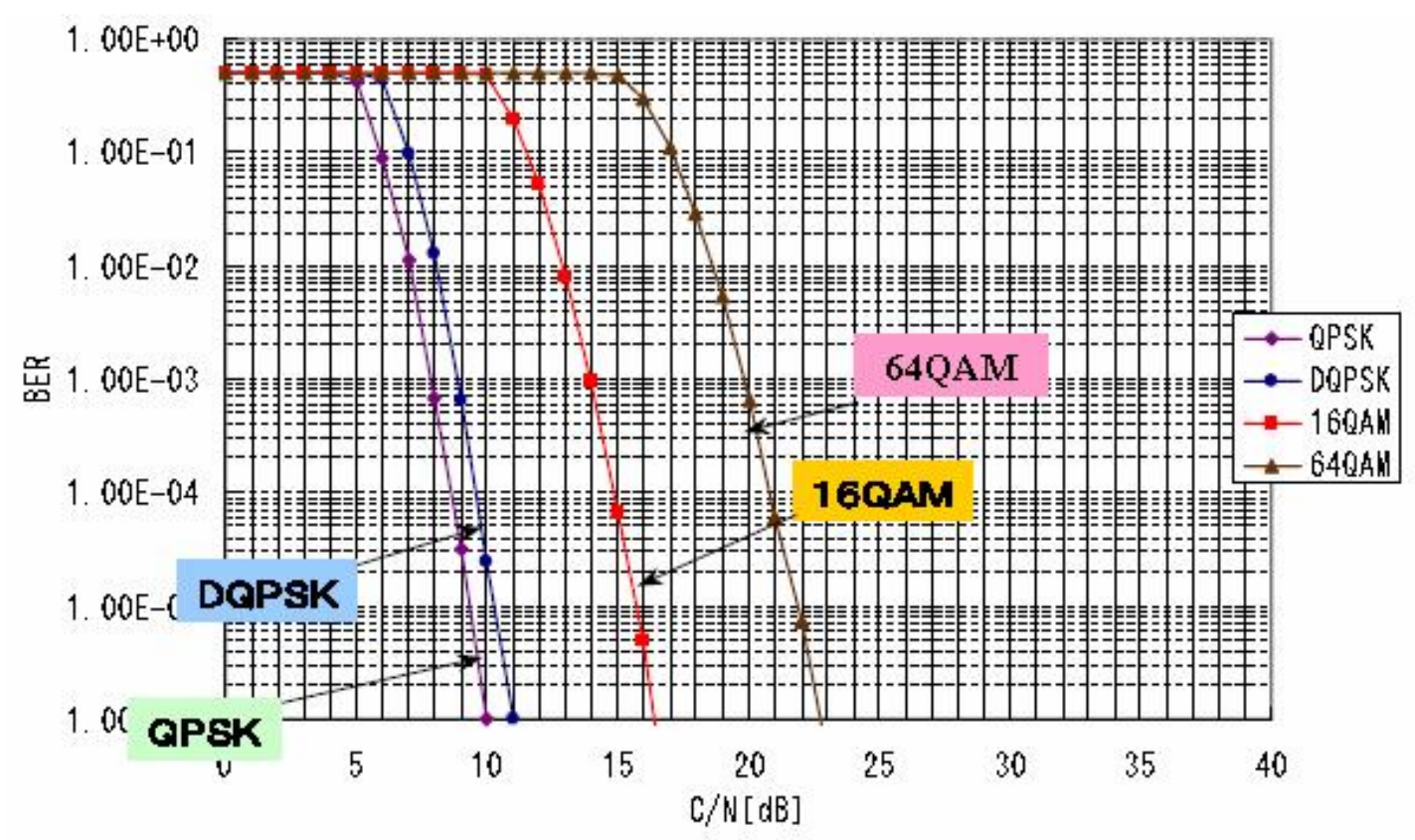

Figura 4.9 Taxa de BER para diferentes taxas de codificação para diferentes modulações [28].

As três camadas de transmissão, A, B e C são combinadas e entrelaçadas no tempo (100, 200 ou $400 \mathrm{~ms})$ e em freqüência por um algoritmo aleatorizador. É adicionada então uma estrutura sincronizadora através da inserção de pilotos de referência e controle.

O segundo bloco do modulador é formado por um modulador OFDM que opera nos modos $2 \mathrm{k}, 4 \mathrm{k}$ ou $8 \mathrm{k}$. No último estágio do modulador é inserido o intervalo de guarda entre os símbolos para que o sinal se torne mais resistente às interferências intersimbólicas. 


\section{A TV DIGITAL NO BRASIL}

\subsection{INTRODUÇÃO}

No dia 29 de junho de 2006 foi assinado o decreto que define a implantação do Sistema Brasileiro de Televisão Digital Terrestre (SBTVD-T) e estabelece diretrizes para a transição do sistema de transmissão analógica para o sistema de transmissão digital. O SBTVD-T adotará, como base, o padrão de sinais do sistema japonês ISDB-T (Integrated Services Digital Broadcasting Terrestrial), mas incorporará inovações tecnológicas resultantes de pesquisas desenvolvidas por universidades e institutos de pesquisas brasileiros.

Segundo esse decreto, o acesso ao SBTVD-T será assegurado, ao público em geral, de forma livre e gratuita, possibilitando transmissão digital em alta definição (HDTV) e em definição padrão (SDTV), transmissão digital simultânea para recepção fixa, móvel e portátil e a interatividade.

$O$ decreto estabelece também que as emissoras de TV receberão um canal de radiofreqüência com largura de banda de $6 \mathrm{MHz}$ para cada canal analógico que possuam. Elas terão um prazo máximo de dois anos para iniciar a transmissão digital neste novo canal. A transmissão analógica continuará ocorrendo, mas foi estabelecido um prazo de dez anos para que toda transmissão terrestre no País seja digital. Durante esse período, o consumidor continuará a receber a TV aberta da forma atual utilizando a sua TV analógica ou poderá adquirir um conversor (set top box) que permitirá receber o sinal digital e convertê-lo para um formato de vídeo e áudio analógicos compatível com seu receptor de TV, ou ainda adquirir uma TV nova que já incorpore o conversor. 
Após o período de dez anos, as emissoras de TV deverão devolver os canais utilizados para a transmissão analógica. Além disso, a partir de julho de 2013 somente serão outorgados canais para a transmissão em tecnologia digital.

Os primeiros estudos sobre a transição do atual sistema de radiodifusão analógica para o padrão digital tiveram início em 1994. Desde então, a busca pela escolha de que caminho seguir para a adoção dessa tecnologia foi constituída de vários acontecimentos, como consultas públicas pela ANATEL, testes de transmissão com os padrões existentes, estudos e elaboração de relatórios feitos pelo $\mathrm{CPqD}, \mathrm{ABERT}$ e SET, estipulação e posteriormente adiamento de prazos para a escolha do padrão, até a decisão estabelecida no decreto mencionado acima.

A demora na definição do padrão de televisão digital adotado pelo Brasil foi causada pela alta complexidade do tema. Foram realizados diversos estudos e testes de campo para melhor conhecer os aspectos técnicos de cada um dos sistemas e para verificar a sua adequação à realidade brasileira. Outros pontos considerados no processo de decisão foram os fatores sócio-econômicos e culturais, já que uma das principais metas da TV digital é promover a democratização da informação.

A escolha do padrão de TV digital tornou-se ainda mais difícil por ter, também, o envolvimento dos interesses econômicos das emissoras de televisão, que fizeram pressão para que fosse escolhido o sistema que lhes proporcionasse maior vantagem.

\subsection{TESTES DE CAMPO}

Minuciosos testes de laboratório e de campo foram realizados no Brasil com o objetivo de comparar o desempenho de transmissão e recepção dos três sistemas de televisão digital existentes: o ATSC, o DVB-T e o ISDB-T. Os resultados dos testes foram relatados no "Relatório Integrador dos Aspectos Técnicos e Mercadológicos da TV Digital" produzido pelo CPqD.

Em fevereiro de 2000, como um dos primeiros resultados dos testes, concluiuse que a modulação $8 \mathrm{VSB}$, adotada como padrão americano, não atendia às necessidades do telespectador brasileiro pelo seu desempenho insuficiente na recepção residencial, especialmente quando são utilizadas antenas internas. Este fato ensejou que a ANATEL colocasse em consulta pública a utilização, na futura TV 
digital brasileira, do COFDM, comum aos padrões europeu e japonês. O padrão ISDB-T foi o que apresentou o melhor desempenho de recepção nos ambientes residenciais.

O relatório final dos testes de TV digital, publicado em maio de 2000 pelo $\mathrm{CPqD}$, confirmou o melhor desempenho dos padrões europeu e japonês, além do desempenho insuficiente do padrão norte-americano nos quesitos transmissão de sinais em áreas de sombra e para receptores móveis. Mais ainda, o padrão japonês, foi julgado superior ao sistema europeu, no que diz respeito à recepção de sinais televisivos em ambientes fechados, assim como pela sua flexibilidade para recepção de programas ou para acesso a serviços, através de terminais fixos ou móveis. O padrão ISDB-T também apresentou desempenho muito superior aos outros padrões no que se refere à imunidade aos ruídos impulsivos.

Neste mesmo relatório foi concluído que o sistema americano ATSC não atende tecnicamente às necessidades mínimas para a preservação do serviço de radiodifusão de sons e imagens no Brasil, principalmente devido a sua baixa robustez a multi-percursos e a sua baixa flexibilidade, se comparado com os sistemas DVB-T e ISDB-T.

Os sistemas DVB-T e ISDB-T foram considerados aptos para atender às exigências de melhorar ou, pelo menos, replicar a recepção dos atuais canais analógicos, permitindo o transporte de sinais de HDTV, além de agregar novas aplicações para os radiodifusores brasileiros.

O sistema ISDB-T foi considerado significativamente superior ao DVB-T no que tange à imunidade ao rú́do impulsivo, bem como ao desempenho para recepção portátil ou móvel, importante para assegurar a competitividade do serviço de radiodifusão de sons e imagens no futuro, além de oferecer maior flexibilidade de aplicações.

Apesar da superioridade técnica e de flexibilidade do sistema ISDB-T, há necessidade de serem considerados outros aspectos, tais como, o impacto que a adoção de cada sistema terá sobre a indústria nacional, as condições e facilidades de implementação de cada sistema, os prazos para sua disponibilidade comercial, o preço dos receptores para o consumidor, a expectativa de queda desses preços, de modo a possibilitar o acesso mais rápido a todas as camadas da população. 


\subsection{O QUE O ISDB TEM A OFERECER}

O ISDB-T apresenta algumas vantagens de grande valor para os interesses que o Brasil tem em relação à TV digital. Inicialmente podemos citar o desempenho apresentado pelo padrão japonês nos testes realizados em algumas cidades do País. O ISDB-T mostrou ser a plataforma mais apropriada para as características das cidades brasileiras, em especial os grandes centros urbanos, que serão os primeiros a receber as transmissões de TV digital. Essas cidades sofrem com problemas causados pela propagação multi-percurso e pelo ruído impulsivo. Nessas duas situações o ISDB-T teve desempenho superior ao sistema DVB-T, enquanto que o sistema ATSC teve desempenho inaceitável quanto à qualidade desejada.

Além disso, o ISDB-T apresenta um número superior de configurações de operação, sendo a plataforma de TV digital existente mais flexível, o que faz com que seja mais facilmente adaptável aos diversos cenários que podem ser encontrados pelo País.

Segundo a ministra da Casa Civil, Dilma Rousseff, o novo sistema foi o escolhido porque promete atingir todas as regiões do País, pois a capacidade de recepção em diversas condições geográficas gera os fatores essenciais na implantação desse padrão. Isso porque o Brasil possui atualmente cerca de $48 \%$ dos televisores brasileiros funcionando com antena interna, o que inviabilizaria um sistema que não contemplasse uma boa qualidade de sinal. Nos testes de campo o sistema ISDB-T foi o que obteve o melhor desempenho no caso de recepção somente com antena interna. Com a adoção do ISDB-T os usuários vão continuar gozando dessa condição, o que barateará a transição do sistema analógico para o digital, pois as pessoas inicialmente só precisarão comprar um conversor de sinais para ter acesso à programação da TV digital a ser implantada e não haverá necessidade de comprar uma antena externa para garantir uma recepção com qualidade.

Em entrevista à TV Senado, o Ministro das Comunicações, Hélio Costa, assegurou que um dos grandes motivadores da escolha do ISDB-T como padrão de TV digital foi o fato de o Japão ter retirado todos os royalties que deveriam ser pagos a aquele País para utilizar sua tecnologia, além do comprometimento de investir 500 milhões de dólares para a implantação de uma fábrica de semi-condutores no Brasil.

No decreto assinado pelo Presidente Luís Inácio Lula da Silva, que institui o ISDB-T como padrão de televisão digital do Brasil, não há garantias explícitas de instalação da fábrica de semi-condutores, o documento apenas declara que "o 
governo japonês valoriza as empresas japonesas que cooperem com nos vários estudos para a modernização das indústrias relacionadas a serem feitos pelo Brasil, e estudem a possibilidade investimentos futuros na indústria eletroeletrônica, incluindo a indústria de semicondutores e correlatos e cooperação na capacitação de recursos humanos".

Apesar da superioridade técnica apresentada pelo sistema ISDB, não é possível afirmar que a implantação do mesmo no Brasil alcançará o mesmo patamar de aceitação que o sistema obteve no Japão. Isso se deve ao fato do Brasil ser um País com características sócio-econômicas, culturais e geográficas muito diferentes daquele País.

Ao contrário do Japão, o Brasil é um País de grande extensão territorial, apresentando contrastes de regiões altamente povoadas e outras de baixa densidade demográfica. Além disso, a renda per capta e o índice de desenvolvimento humano brasileiro estão muito aquém daqueles apresentados no Japão. Todos esses fatores fazem com que não seja possível prever se a TV digital obterá o mesmo êxito no Brasil.

Quanto à extensão territorial e a baixa densidade demográfica, podemos ter um elevado custo para implantação da rede, principalmente nas áreas mais remotas. Em países que apresentam esse quadro, como os estados Unidos, a medida adotada foi a diferenciação quanto ao critério de implantação, sendo que o serviço foi implantado primeiramente em regiões mais densas. Apesar do Japão não ter passado por situação semelhante, o ISDB apresenta a opção da oferta do serviço por satélite, o que poderia ajudar quanto à inclusão de todas as regiões nessa oferta.

A escolha do padrão de televisão digital brasileiro foi marcada pela disputa entre emissoras de TV e operadoras de celular. Ambas possuíam interesses econômicos na escolha, pois com a implantação da TV digital existe a promessa de criação de novos serviços com potencial de aumentar o faturamento dessas entidades.

As emissoras de televisão ganharam essa batalha com a escolha do ISDB-T. Isso porque com o sistema escolhido as transmissões para celulares serão feitas diretamente pelas emissoras de televisão, enquanto que com o sistema europeu, o DVB-T, as operadoras de celular seriam intermediárias neste processo, levando uma fatia do faturamento de um serviço totalmente novo que promete gerar grande receita caso seja bem explorado. 
Um dos fatores bastante discutidos durante a tomada de decisão foi a possibilidade de se comercializar a tecnologia. Pensando-se em obter o maior mercado de exportação parece bastante racional adotar um padrão que seja compatível com o DVB-T, apesar deste sistema não ter sido o mais bem sucedido nos testes realizados. Isso porque além deste sistema ser um padrão aberto, foi adotado pelos países europeus e ainda pela África do Sul e Índia que, junto com o Brasil, compõem o G3 e vêm sendo priorizados nas relações comerciais brasileiras.

No entanto, nenhum dos países que adotaram o DVB-T até o presente momento utiliza a canalização de televisão adotada no Brasil, que é de $6 \mathrm{MHz}$. Essa incompatibilidade isolaria o Brasil do restante do mundo e criaria uma reserva de mercado inaceitável, restringindo o mercado exportador e impedindo a queda de preços possibilitada pela concorrência externa.

O sistema ATSC é o que apresenta maior mercado para exportação pois foi adotado em diversos países com a mesma canalização utilizada no Brasil, no entanto, este sistema foi descartado por não apresentar resultados satisfatórios nos testes de campo. O sistema ISDB-T tem a possibilidade de comercialização somente com o Japão, mas não é descartada a hipótese desse sistema ser adotado por algum outro País.

Outro ponto a ser considerado na escolha do padrão de televisão digital foi o custo que o telespectador deverá arcar para se beneficiar da nova tecnologia. Segundo relatório divulgado pelo $\mathrm{CPqD}$, o preço de venda do set top box projetado para o DVB em 2006 está entre $R \$ 233,00$ (básico) e $R \$ 662,00$ (avançado). Os preços seriam de $8 \%$ a $10 \%$ maiores para o padrão ATSC e de $15 \%$ a $18 \%$ para o ISDB.

O sistema escolhido para operar no Brasil é o que apresenta um custo inicial mais elevado para o telespectador. No entanto, como demonstrado nos testes, o sistema ISDB-T permite a plena recepção de televisão apenas com a antena interna - a realidade de mais de $60 \%$ dos brasileiros. Isso traz um economia para o consumidor que gastaria mais com o set top box, mas não precisaria instalar uma antena externa para receber o sinal de televisão digital com qualidade.

\subsection{A TV DIGITAL PARA AS EMISSORAS}

É inegável a importância da TV como mecanismo de entretenimento e obtenção de informação, sendo essa a mídia de comunicação mais utilizada pela 
população brasileira. É importante que as emissoras de televisão procurem investir em seu desenvolvimento tecnológico a fim de continuar proporcionando serviços de qualidade para esse elevado número de usuários.

A digitalização da plataforma de transmissão terrestre de sinais de televisão tem como meta proporcionar vantagens aos radiodifusores e atingir esse enorme público que usufrui desse serviço. Para as emissoras de televisão, essa digitalização possibilitará o aperfeiçoamento dos seus sistemas, a formulação de novos tipos de programas e de exploração de novas possibilidades de serviço. Já para o público, como mencionado anteriormente, essa mudança representa o surgimento de uma nova visão da televisão, com mais qualidade e interatividade.

A migração das emissoras para o sistema digital apresenta importantes benefícios, como o aprimoramento tecnológico e a introdução de novas funcionalidades ao serviço, será também uma oportunidade de evolução para se manterem competitivas face aos avanços tecnológicos verificados em outras áreas, tais como na TV por assinatura e na Internet.

Essa migração acarreta também em custos. De acordo com o Grupo Técnico da ABERT/SET, o custo de implantação do sistema digital em uma geradora varia de U\$ 500 mil a U\$ 5,2 milhões, dependendo de seu porte e de condições específicas de infra-estrutura. Da mesma forma, no caso de retransmissoras, esse número varia de U\$ 80 mil a U\$ 4 milhões. Esses custos podem até ser viáveis para as emissoras de grande porte, localizadas nas grandes cidades, porém a viabilização é bem mais difícil para as pequenas geradoras e retransmissoras independentes [22].

Quanto à capacidade de investimento, como o quadro apresentado no País vai de pequenas emissoras locais a grandes redes nacionais, a situação é bastante díspare. As grandes redes nacionais consideram-se aptas a realizar a digitalização, apesar de que em alguns casos haverá a necessidade de financiamento para a aquisição de equipamentos. Algumas redes terão condições de digitalizar uniformemente todas as unidades espalhadas pelo País, já outras apresentam condições para inicialmente realizar a migração apenas nos grandes centros. $O$ pior caso são as redes menores, que ainda se encontram no estágio de ampliação de seus sistemas analógicos e não estavam considerando a necessidade de digitalizar [22].

Com relação ao cronograma de implantação dos serviços de TV digital, foi feita uma pesquisa quantitativa onde apresentaram para as emissoras uma estimativa de custos para a digitalização tendo como ponto inicial os equipamentos atualmente existentes e a potência transmitida daquela emissora. Com base nesse 
resultado, foi questionado qual seria a estimativa para que a emissora passasse a transmitir digitalmente. O gráfico mostrado na Figura 5.1 ilustra o resultado dessa pesquisa [22].

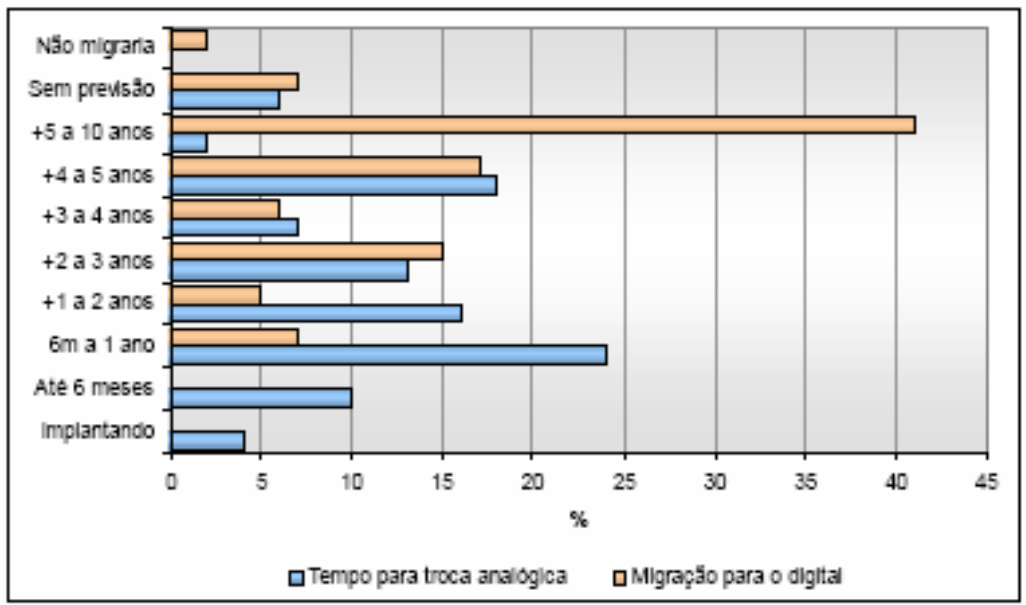

Figura 5.1 - Tempo estimado para realizar (1) ampliação ou troca dos equipamentos com a tecnologia corrente e (2) conversão para o sistema digital [22].

Pelo gráfico da Figura 5.1, é possível perceber que a melhor estimativa para a troca de equipamentos é de 6 meses a 1 ano, isso porque em algumas emissoras, boa parte dos equipamentos já é de tecnologia digital. Com relação à migração, é possível perceber que a maioria aposta num prazo de 5 a 10 anos. 


\section{CONCLUSÃO}

A evolução da humanidade sempre foi pautada na busca de inovações e pelo aprimoramento das técnicas já existentes. O surgimento da TV Digital é mais um exemplo de um grande investimento em desenvolvimento tecnológico.

Esse trabalho procurou abordar os principais pontos dessa inovação tecnológica, seus conceitos e principalmente as vantagens que essa transformação traz para a sociedade e para os meios de comunicação.

Como mencionado, a lista de vantagens da TV Digital é muito interessante e atrativa: melhoria na qualidade da imagem e do áudio, uma diversidade muito maior de programação, facilidade no acesso à informação, interatividade, convergência da televisão com outras tecnologias e tantas outras vantagens que ainda estão apenas na imaginação dos grandes investidores do setor, que apostam na criatividade para explorar principalmente a questão da interatividade, gerando diversos serviços.

Por ser uma questão complexa que envolve não só aspectos técnicos, mas também econômicos e sociais, a escolha do padrão de televisão digital brasileiro foi um processo bastante demorado. Desde o início do processo até a definição do sistema escolhido passaram-se mais de 10 anos de estudos e debates sobre qual das plataformas seria a mais adequada ao perfil brasileiro.

Dentre as possibilidades de escolha estavam os sistemas ATSC, americano, o DVB-T, europeu e o ISDB, japonês. O padrão americano foi descartado depois das realizações de alguns testes de campo, em que foi detectado que este não atendia os requisitos mínimos exigidos pelo Decreto №. 4901, de 26 de outubro de 2003.

A disputa ficou então entre os padrões DVB e ISDB. O padrão japonês apresentou o melhor desempenho nos testes de campo, principalmente quanto à capacidade de recepção interna, que é a realidade de mais da metade dos lares brasileiros. Além disso, esse sistema é o mais flexível, apresentando diversos modos 
de operação, podendo ser adaptado a um número maior de situações que o sistema europeu.

No Decreto №. 4901, um dos requisitos exigidos pelo governo para o novo sistema de televisão digital era a capacidade de transmitir com eficiência para receptores móveis e portáteis. Nos testes de campo o ISDB-T novamente apresentou desempenho superior ao DVB. O ISDB é também o único sistema capaz de transmitir para receptores móveis sem precisar utilizar banda adicional aos $6 \mathrm{MHz}$ destinados a cada canal de TV, já que a plataforma ATSC não disponibiliza esse serviço e o DVB utiliza o serviço das operadoras de celular para intermediar esse tipo de transmissão. Esse foi um dos motivos que levou o governo brasileiro a adotar o ISDB como o padrão nacional de TV digital.

Finalmente, em 29 de junho de 2006, o Governo Brasileiro assinou o Decreto №. 5820 que define o regime de transição da televisão analógica brasileira para o sistema digital. O Sistema Brasileiro de Televisão Digita Terrestre, SBTVD-T, adotará a tecnologia japonesa (ISDB-T) e também fará uso dos resultados de pesquisas que foram desenvolvidos pelas universidades e institutos brasileiros.

Segundo esse decreto, o acesso ao SBTVD-T será assegurado, ao público em geral, de forma livre e gratuita, possibilitando transmissão digital em alta definição (HDTV) e em definição padrão (SDTV), transmissão digital simultânea para recepção fixa, móvel e portátil e a interatividade.

Foi estabelecido nesse decreto que as emissoras de TV receberão um canal de radiofreqüência com largura de banda de $6 \mathrm{MHz}$ para cada canal analógico que possuam. O prazo estipulado pra que a transmissão digital seja iniciada nesse novo canal é de dois anos. Outro prazo determinado foi com o período de 10 anos para que toda a transmissão terrestre no País seja digital. Durante esse período a transmissão analógica continuará ocorrendo, sendo que o consumidor terá a opção de continuar a receber a TV aberta da forma atual ou adquirir os equipamentos necessários para fazer uso dos serviços oferecidos pela TV digital. Expirando esse período de 10 anos, as emissoras de TV deverão devolver os canais utilizados para a transmissão analógica. Além disso, a partir de julho de 2013 somente serão outorgados canais para a transmissão em tecnologia digital.

O Governo Brasileiro atribuiu a escolha do padrão japonês ao fato deste ter apresentado o melhor desempenho no caso de recepção utilizando apenas antena interna - realidade de mais da metade da população brasileira - porque neste caso não demandaria da população nenhum custo adicional além da compra de um set top box. Outros fatores atrativos que levaram o Governo a escolher o sistema ISDB- 
T foram os incentivos econômicos oferecidos pelo governo japonês, que retirou todos os royalties que seriam cobrados para a adoção da plataforma no Brasil e também prometeu investir 500 milhões de dólares no desenvolvimento da indústria eletroeletrônica nacional.

A escolha do padrão de TV digital japonês não significa, no entanto, que toda a pesquisa desenvolvida no Brasil terá sido em vão. No decreto o Governo afirma que parte da tecnologia desenvolvida no País poderá ser utilizada no SBTVD.

O desenvolvimento de um sistema totalmente brasileiro, idéia defendida por muitos, parece ser uma alternativa inviável para a realidade brasileira. Todos os três sistemas de televisão digital existentes levaram quase uma década para serem projetados e construídos, e foram necessários bilhões de dólares para serem desenvolvidos. Se o Brasil fosse desenvolver seu próprio sistema, além de esperarmos muitos anos para poder usufruir dos benefícios da TV digital, a realidade econômica do País talvez não permitisse que tal feito fosse concretizado.

Por todos os motivos expostos nesse trabalho, acreditamos que a decisão do governo de adotar o sistema ISDB-T como padrão brasileiro de TV digital foi bastante coerente. No entanto, não é possível prever se a televisão digital obterá êxito no Brasil, visto que a nossa situação econômica e social é bastante diferente da encontrada no Japão e em outros países onde a TV digital é um sucesso.

$\mathrm{O}$ Brasil apresenta graves problemas relacionados à baixa renda $\mathrm{e}$ desemprego. Por mais que o Governo acredite que reduzindo o custo dos receptores para TV digital, a aceitação da TV digital será maior, a reflexão que surge é sobre a relevância que será dada a uma imagem em HDTV e a qualidade de áudio como se estivesse no cinema, se grande parte da população já possui seu aparelho de TV e há tantas outras necessidades básicas a serem levadas em conta. 


\section{REFERÊNCIAS}

[1] PNAD 2004 - Pesquisa Nacional por amostra de Domicílio. IBGE

[2] Ministério das Comunicações - Disponível em: www.mc.gov.br

[3] Notícias CPqD - Disponível em:www.cpqd.com.br

[4] E . Oliveira, C. Ribeiro, C. Albuquerque: "TV Digital Interativa: Padrões Para Uma Nova Era".

[5] V. Sablón, I. Becerra, Y. Iano, A. Pietro, R. Togni, L. Mendes: "Subsistemas de Compressão e codificação do sinal de vídeo (parte l)", Departamento de Comunicações - Unicamp, Disponível em: www.inatel.br

[6] Y. Iano, L Mendes, V. Sablón e B. Idalberto : "Televisão Digital de Alta Definição

- HDTV", Consultado em: www.inatel.br/revista/volume-03-n1/pdf/artigo01.pdf

[7] TV Digital - "A Digitalização dos Sinais de TV Analógica", Unicamp, Disponível em: www.mediatec.iar.unicamp.br/CS305/tvdigital.htm

[8] TV Digital, Disponível em: www.geocities.yahoo.com.br/telestacio2001/tv_digital

[9] HDTV Advanced Inc. Ltda, "Introdução a Televisão de Alta Definição", Disponível em:http://paginas.terra.com.br/servicos/AdvancedRF/at5.htm

[10] Universidade Fernando Pessoa: "Informação digital e Interatividade", Acessado em: http://cerem.ufp.pt/ nribeiro/aulas/pii/mult02.pdf

[11] EPCOM - Instituto de Estudos e Pesquisas em Comunicação: "Relatório TV Digital - Análise do processo de implementação da tecnologia digital na mídia eletrônica do Brasil e subsídios para o conhecimento e a ação da sociedade e dos cidadãos na busca das melhores possibilidades culturais, políticas e econômicas", Disponível em: http://www.fndc.org.br

[12] Revista Mackenzie de Engenharia e Computação, Ano 5, n.5, p.13-96: "Sistema de TV Digital", Disponível em: www.mackenzie.com.br/revistas 
[13] DVB-H Handheld - "Transmissão de IP para dispositivos de mão com base em DVB-T", Disponível em: www.dvb.org/documents

[14] Sistema Brasileiro de TV Digital - Disponível em: www.cpqd.com.br/sbtvd-in

[15] Agência Nacional de Telecomunicações - ANATEL, Consultado em: www.anatel.gov.br

[16] J. Fernandes, G. Lemos e G. Silveira: "Introdução à Televisão Digital Interativa: Arquitetura, Protocolos, Padrões e Práticas", Jornada de Atualização em Informática do Congresso da Sociedade Brasileira de Computação, JAI-SBC, Agosto de 2004, Disponível em: http://www.cic.unb.br

[17] Revista Mackenzie de Engenharia e Computação, Ano 5, n.5, p.13-96: "Processos de Compressão", Disponível em: www.mackenzie.com.br

[18] T. Saito, A. Hashimoto e F. Minematsu, "ISDB-T - Digital Terrestrial Television/Sound/Data Broadcasting in Japan -", Japan Broadcasting Corporation, Disponível em: http://www.nhk.or.jp/strl/publica/bt/en/pa0006.html

[19] Digital Experts Group, "Flexibilidade", Comentários ao Relatório do CPqD, Junho de 2001. Consultado em: http://www.dibeg.org/techp/techp.htm

[20] Digital Experts Group, "Recepção Móvel”, Comentários ao Relatório do CPqD, Junho de 2001. Consultado em: http://www.dibeg.org/techp/techp.htm

[21] ARIB STANDARD (ARIB STD - B31): "Transmission System for Digital Terrestrial Television Broadcasting", Janeiro 2002, Disponível em: http://www.dibeg.org/aribstd/ARIBSTD.htm

[22] CPqD - "Análise das Condições Brasileiras para a Introdução da Tecnologia Digital na Transmissão Terrestre de Televisão", Projeto Modelo de Implantação da TV Digital no Brasil: Consultado em: www.anatel.gov.br

[23] Silva, L., Lima, F., Lopes, D., Júnior, H.: "Radiodifusão Sonora Digital Terrestre -Sistemas Existentes e suas Principais Características", Departamento de Engenharia Elétrica, Universidade de Brasília, Fevereiro 2005.

[24] L. Resende: "Desenvolvimento de uma Ferramenta de Análise de Desempenho para o Padrão de TV Digital ISDB-T", Departamento de Engenharia Elétrica PUC- RJ, Maio 2004.

[25] T. Saito, A. Hashimoto e F. Minematsu, "ISDB-S - Satellite Transmission System for Advanced Multimedia Services Provided by Integrated Services Digital Broadcasting", Japan Broadcasting Corporation, Disponível em: http://www.nhk.or.jp/strl/publica/bt/en/pa0005.html 
[26] K. Oyamada, T. Kurakake e H. Miyazawa, "ISDB-C - Cable Television Transmission for Digital Broadcasting in Japan", Japan Broadcasting Corporation, Disponível em: http://www.nhk.or.jp/strl/publica/bt/en/pa0007.html

[27] ARIB - "Specification of chanel coding, frame structure and modulation" Consultado em : www.dibeg.org

[28] Y. Takahashi, "Transmission System", Toshiba Corporation, Seminário em Campinas, SP, Março 2005, Disponível em: http://www.dibeg.org/ 